\title{
c-Met inhibitors attenuate tumor growth of small cell hypercalcemic ovarian carcinoma (SCCOHT) populations
}

\author{
Anna Otte ${ }^{1}$, Finn Rauprich ${ }^{1}$, Juliane von der Ohe ${ }^{1}$, Yuanyuan Yang ${ }^{1}$, Friedrich \\ Kommoss $^{2}$, Friedrich Feuerhake ${ }^{3}$, Peter Hillemanns ${ }^{1}$, Ralf Hass ${ }^{1}$ \\ ${ }^{1}$ Biochemistry and Tumor Biology Laboratory, Department of Obstetrics and Gynecology, Hannover Medical School, Hannover, \\ Germany \\ ${ }^{2}$ Synlab MVZ Pathologie Mannheim GmbH, Referral Center for Gynecopathology, Mannheim, Germany \\ ${ }^{3}$ Institute for Pathology, Hannover Medical School, Hannover, Germany \\ Correspondence to: \\ Ralf Hass, e-mail: hass.ralf@mh-hannover.de
}

Keywords: SCCOHT, small cell ovarian cancer, c-Met inhibitor, foretinib, tumor growth

Received: February 16, $2015 \quad$ Accepted: August 12, $2015 \quad$ Published: September 30, 2015

\section{ABSTRACT}

A cellular model (SCCOHT-1) of the aggressive small cell hypercalcemic ovarian carcinoma demonstrated constitutive chemokine and growth factor production including HGF. A simultaneous presence of c-Met in $41 \%$ SCCOHT-1 cells suggested an autocrine growth mechanism. Expression of c-Met was also observed at low levels in the corresponding BIN-67 cell line (6.5\%) and at high levels in ovarian adenocarcinoma cells (NIH:OVCAR-3 (84.4\%) and SK-OV-3 (99.3\%)). Immunohistochemistry of c-Met expression in SCCOHT tumors revealed a heterogeneous distribution between undetectable levels and $80 \%$. Further characterization of SCCOHT-1 and BIN67 cells by cell surface markers including CD90 and EPCAM demonstrated similar patterns with differences to the ovarian adenocarcinoma cells. HGF stimulation of SCCOHT-1 cells was associated with c-Met phosphorylation at Tyr $^{1349}$ and downstream $\mathrm{Thr}^{202} / \mathrm{Tyr}^{204}$ phosphorylation of $\mathrm{p} 44 / 42$ MAP kinase. This HGF-induced signaling cascade was abolished by the c-Met inhibitor foretinib. Cell cycle analysis after foretinib treatment demonstrated enhanced $\mathbf{G 2}$ accumulation and increasing apoptosis within $72 \mathrm{~h}$. Moreover, the IC $_{50}$ of foretinib revealed $12.4 \mathrm{nM}$ in SCCOHT-1 cells compared to $411 \mathrm{nM}$ and $481 \mathrm{nM}$ in NIH:OVCAR-3 and SK-OV-3 cells, respectively, suggesting potential therapeutic effects. Indeed, SCCOHT-1 and BIN-67 tumor xenografts in NOD ${ }^{\text {scid }}$ mice exhibited an approximately 10 -fold and 5 -fold reduced tumor size following systemic application of foretinib, respectively. Furthermore, foretinib-treated tumors revealed a significantly reduced vascularization and little if any c-Met-mediated signal transduction. Similar findings of reduced proliferative capacity and declined tumor size were observed after siRNA-mediated c-Met knockdown in SCCOHT-1 cells demonstrating that in vivo inhibition of these pathways contributed to an attenuation of SCCOHT tumor growth.

\section{INTRODUCTION}

One of the most lethal gynecologic malignancies is caused by ovarian cancer. A variety of different epithelial ovarian cancers have been categorized into two types, whereby type I tumors include low-grade serous, endometrioid, clear cell and mucinous carcinomas which appear clinically indolent. In contrast, type II tumors are characterized by high-grade serous, high-grade endometrioid and undifferentiated carcinomas, as well as malignant mixed mesodermal tumors (carcinosarcomas) with papillary, glandular, and solid patterns displaying highly aggressive cancer cells predominantly observed in advanced tumor stages [1-3]. This differentiated histopathological categorization of ovarian tumor types is also supported by molecular differences. Thus, gene mutations including KRAS, BRAF, ERBB2, PTEN, CTNNB1, and PIK3CA are predominantly detected in 
type I ovarian tumors. Vice versa, type II tumors often display genetic instabilities with a high frequency of TP53 mutations and cyclin E1 amplifications which directly regulate the proliferative capacity and cell cycle progression $[4,5]$.

Upon variations of this type of malignant neoplasia, the small cell ovarian carcinoma of the hypercalcemic type (SCCOHT) represents a rare form of an aggressive ovarian tumor which is predominantly observed in young women between ages of 13 to 35 . The SCCOHT has a poor prognosis and is associated in most cases with paraendocrine hypercalcemia $[6,7]$.

Histopathological evaluation of several clinical cases have classified the SCCOHT as a separate pathological entity [6] since this tumor appears different from other ovarian cancer types including ovarian epithelial tumors and ovarian germ cell tumors [8]. However, the etiology of the SCCOHT still remains obscure. Whereas immunohistochemical analysis of the SCCOHT postulated a germ cell-derived tumor [9], other work has also discussed SCCOHT as an epithelial-like originating tumor [7] and genetic analysis of SCCOHT tumor specimen have documented an inhomogeneous tumor entity [10-12]. Genome sequencing of SCCOHT tumor biopsies revealed both, germline and somatic mutations of the SMARCA4 gene including a stop codon mutation p.Arg1077* and a frameshift p.Pro1180fs [13]. The SMARCA4 gene encodes the transcription activator BRG1 which represents an ATP-dependent helicase of the SWI/SNF family and its mutation was suggested as a potential molecular marker for the SCCOHT [14-16].

Cellular models for the SCCOHT are represented by the BIN-67 [17] and the SCCOHT-1 [18] cell lines. In line with the SCCOHT histology, characterization of BIN67 and SCCOHT-1 tumor cells indicated heterogeneous populations with certain epithelial and mesenchymal properties. Moreover, SCCOHT-1 tumor cells are carrying a defective SMARCA4 gene with a loss of BRG1 protein expression [19] and likewise, BIN-67 cells demonstrated biallelic deleterious SMARCA4 gene mutations [15] which confirms the results in SCCOHT patient biopsies. Whereas mutations in the SMARCA4 gene and the related SMARCB1 gene also occur in malignant rhabdoid tumors, further similarities by whole exome sequencing suggested SCCOHT as malignant rhabdoid tumor of the ovary [20]. Furthermore, BIN-67 and SCCOHT-1 cells developed appropriate tumors in xenotransplants and exhibited multiple chemotherapeutic resistances by continued tumor growth [21, 22]. Consistently, various resistant effects are also observed in SCCOHT patients and therefore, reasonable approaches for the treatment of this tumor disease remain unknown. It was thus the aim of the present study, to identify a potential molecular target for a growth arrest of these tumor cells by investigating effects of growth factors such as HGF and the related receptor c-Met in SCCOHT-1 cell cultures in comparison to BIN-67 cells and the established human ovarian adenocarcinoma NIH:OVCAR-3 and SK-OV-3 cell line.

\section{RESULTS}

The constitutive production and release of certain cytokines and growth factors by SCCOHT-1 cells was measured in a customized human multiplex ELISA system. Little if any release of ICAM-1, PDGF-BB and TNF- $\alpha$ was detectable in SCCOHT-1 cell culture medium after $24 \mathrm{~h}$ and $48 \mathrm{~h}$, respectively. However, there was a significant production of HGF by $4,868 \pm 464 \mathrm{ng} / 2 \times 10^{5}$ cells after $24 \mathrm{~h}$ which raised to $24,590 \pm 1,580 \mathrm{ng} / 2 \times 10^{5}$ cells $(n=4)$ after $48 \mathrm{~h}$ (Fig.1). Moreover, an increase in IL8 production was also paralleled by elevated PDGF-AA levels from $11 \pm 2 \mathrm{ng} / \mathrm{ml}$ in control medium to $666 \pm 100 \mathrm{ng} / 2 \times 10^{5}$ cells after $24 \mathrm{~h}$ and $2,167 \pm 279 \mathrm{ng} / 2 \times 10^{5}$ cells after $48 \mathrm{~h}$ $(n=4)$, respectively. Likewise, release of VCAM-1 and VEGF was significantly elevated by SCCOHT-1 cells (Fig. 1).

According to the constitutive production and release of HGF by SCCOHT-1 cells, simultaneous expression of the corresponding receptor c-Met was investigated. Analysis by flow cytometry revealed c-Met receptor expression in $6.5 \pm 0.1 \%(n=3)$ of BIN-67 cells, $40.9 \pm 3.8 \%(n=3)$ of SCCOHT-1 cells and a majority in ovarian adenocarcinoma cells with $84.4 \pm 9.2 \%(n=3)$ in NIH:OVCAR-3 cells and $99.3 \pm 0.4 \%(n=3)$ in SK-OV-3 cells (Fig. 2A). Similar results were obtained by Western blots with the lowest levels of c-Met proteins in BIN-67 cells and high expression levels in NIH:OVCAR-3 cells and SK-OV-3 cells (Fig. 2B).

Although different levels of c-Met expression were observed in SCCOHT-1 and BIN-67 cells, these two populations shared a variety of similar markers and could be distinguished from other ovarian adenocarcinoma cells. Flow cytometry analysis revealed a common expression of surface markers for cell-cell communication including the beta-1 integrin subunit CD29 among all of these ovarian cancer populations which i.e. can function as the $\alpha 3 \beta 1$ integrin and may play a role during metastatic diffusion of certain tumor cells. However, marked differences were observed for a variety of other cell surface markers in SCCOHT-1 and BIN-67 cells compared to NIH:OVCAR-3 and SK-OV-3 cells indicating altered tumor cell functionalities. One of these differences included the glycosyl phosphatidyl inositol (GPI)-anchored CD90 antigen expression, also present on some immune cells, hematopoietic stem cells, and a property of mesenchymal stem cells in a normoxic and hypoxic microenvironment $[23,24]$. Increased CD90 and vimentin levels were detected during epithelial to mesenchymal transition of non small cell lung cancer (NSCLC) cells [25] and CD90 protein expression by 


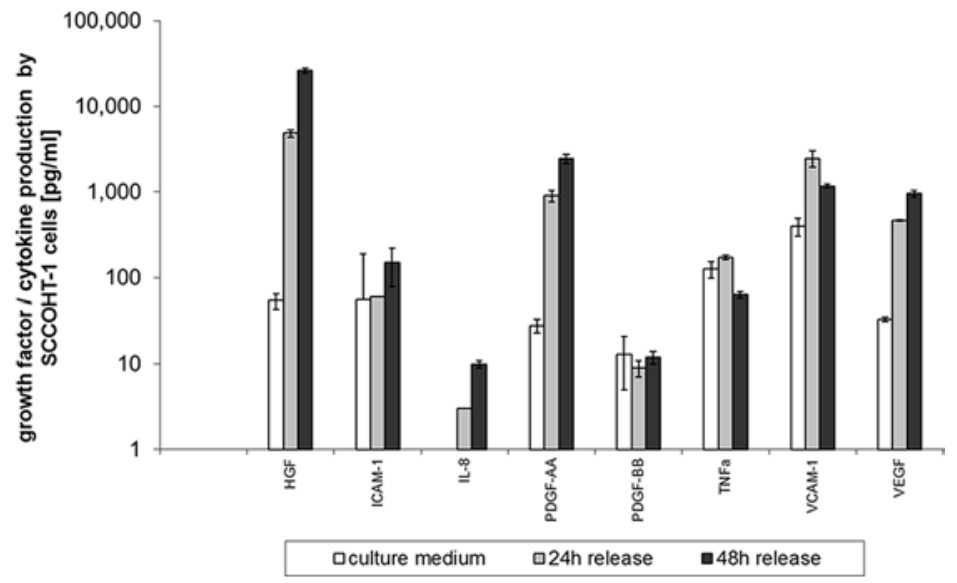

Figure 1: Quantitative production of distinct growth factors and cytokines was measured in supernatants of SCCOHT-1 $\left(2 \times 10^{5}\right.$ cells $\left./ \mathrm{ml}\right)$ after $24 \mathrm{~h}$ and $48 \mathrm{~h}$, respectively, using a multiplexed human chemokine assay system. Data represent the amount of cytokine/growth factor production $\left[\mathrm{pg} / 2 \times 10^{5}\right.$ cells $] \pm$ s.d. $(n=4)$. $(\mathrm{HGF}=$ hepatocyte growth/scatter factor; ICAM-1 = intercellular cell adhesion molecule-1; IL-8 = interleukin-8; PDGF $=$ platelet-derived growth factor; TNFa $=$ tumor necrosis factor-alpha; VCAM-1 = vascular cell adhesion molecule-1; VEGF = vascular endothelial growth factor)

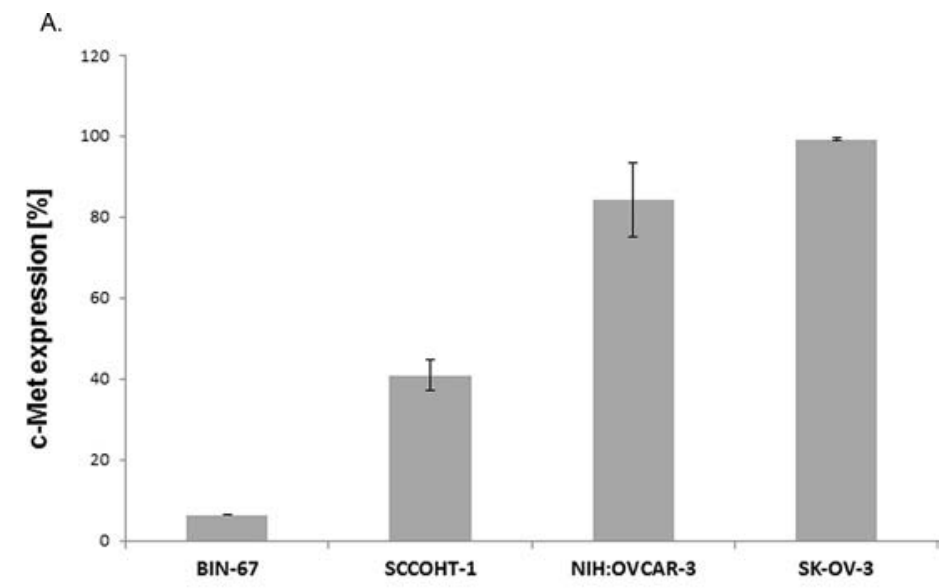

B.

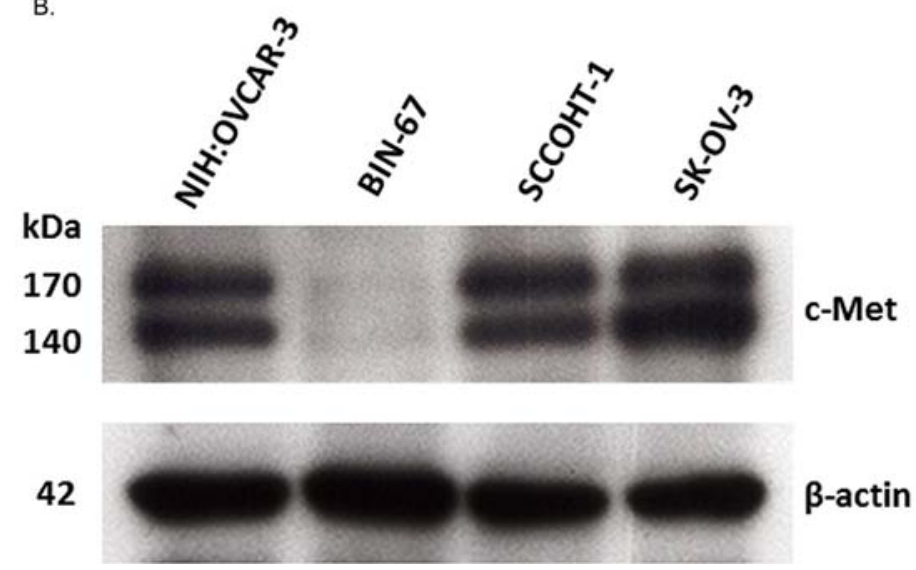

Figure 2: A. Expression of c-Met protein was measured by flow cytometry in BIN-67, SCCOHT-1, NIH:OVCAR-3 and SK-OV-3 cells, respectively. Data represent the percentage of c-Met expression \pm s.d. $(n=4)$. B. Western blot of c-Met expression in the 4 different ovarian cancer cell populations with GAPDH expression as control. 
SCCOHT-1 and BIN-67 cells was in contrast to little if any detectable CD90 in NIH:OVCAR-3 and SK-OV-3 cells (Suppl. Fig. S1). Moreover, mesothelin as part of the outer plasma membrane by GPI linkage is overexpressed in several human tumors, including mesothelioma as well as pancreatic and ovarian adenocarcinoma [26] and was detectable in NIH:OVCAR-3 and SK-OV-3 cells in contrast to SCCOHT-1 and BIN-67 cells. In addition, the epithelial cell adhesion molecule (CD326/EpCAM) functions as a transmembrane glycoprotein mediating $\mathrm{Ca}^{2+}$-independent homotypic cell-cell adhesion in epithelia and in contrast to an extensive expression in NIH:OVCAR-3 and SK-OV-3 cells this adhesion molecule was undetectable in SCCOHT-1 and BIN67 cells. Furthermore, the mesenchymal intermediate filament vimentin could be observed in SCCOHT-1, BIN67 and SK-OV-3 cells and to about 7\% NIH:OVCAR-3 cells. In addition, cytokeratins as part of the epithelial intermediate filament proteins were strongly expressed in NIH:OVCAR-3 and SK-OV-3 cells and only to about $27 \%$ in SCCOHT- 1 and about $2 \%$ in BIN-67 cells (Suppl. Fig. S1). Together, these findings suggested differences in cell-cell and cell-matrix interactions between the small cell hypercalcemic ovarian tumor cell types and the ovarian adenocarcinoma cell lines.

C-Met expression was also examined by immunohistochemistry (IHC) in 16 different SCCOHT patient tumor tissues (Fig. 3). The SCCOHT-1 celloriginating patient tumor demonstrated c-Met expression in about $40 \%$ of the cells (Fig. 3A) which is in line with our flow cytometry data. In addition, a series of 15 centrally reviewed primary SCCOHT was retrieved from the archives of the Mannheim referral center for gynecopathology by one of the authors (FK) and stained for c-Met expression by standard immunohistochemistry. While 6/15 tumors were c-Met negative, 4/15 tumors showed very low levels of c-Met expression $(<1 \%$ positive cells), and 5/15 tumors were weakly to moderately c-Met positive $(<10-80 \%$ positive cells, Fig. $3 \mathrm{~B})$. These results suggest heterogeneity of c-Met expression in individual SCCOHT tumors.

Accordingly, c-Met signaling was investigated in the different ovarian cancer cells. Exogenous stimulation of SCCOHT-1, SK-OV-3 and NIH:OVCAR-3 cells with $20 \mathrm{ng} / \mathrm{ml} \mathrm{HGF}$ was associated with enhanced phosphorylation of c-Met at Tyr1349 after 30 min which was abolished in the presence of $2.5 \mu \mathrm{M}$ crizotinib and $1.25 \mu \mathrm{M}$ foretinib, respectively (Fig. 4). BIN-67 cells demonstrated barely detectable phosphorylation signals due to the low constitutive expression levels of c-Met (Fig. 4). Whereby constitutive c-Met expression remained unaltered, HGF stimulation was also accompanied by downstream signaling of enhanced p44/p42 MAP kinase phosphorylation at Thr202/Tyr204 particularly in SK-OV-3 and NIH:OVCAR-3 cells. Likewise, these
HGF-mediated phosphorylation signals were partially diminished by a parallel incubation with $2.5 \mu \mathrm{M}$ crizotinib and even more reduced in the presence of $1.25 \mu \mathrm{M}$ foretinib (Fig. 4) suggesting the c-Met inhibitor foretinib a potent signaling inhibitor in these tumor cells.

Effects of crizotinib and foretinib were also tested on the cell cycle progression and proliferative capacity of the ovarian cancer cells. Cell cycle analysis after incubation of SCCOHT-1 (Fig. 5A) and BIN-67 cells (Fig. 5B) with $0.25 \mu \mathrm{M}$ up to $1.25 \mu \mathrm{M}$ foretinib or $0.625 \mu \mathrm{M}$ up to $2.5 \mu \mathrm{M}$ crizotinib revealed a significant initial $\mathrm{G} 2 / \mathrm{M}$ accumulation after $12 \mathrm{~h}$ which continuously declined until $72 \mathrm{~h}$ (Fig. 5A, 5B). This was paralleled by a progressively increasing apoptosis in sub G1 phase within $12 \mathrm{~h}$ to $72 \mathrm{~h}$. Moreover, some aberrant mitosis was detectable by DNA doubling without cell division and therefore, appearance of populations with $2 \times \mathrm{G} 2 / \mathrm{M}$ or more DNA content $(>2 \times \mathrm{G} 2 / \mathrm{M})$ (Fig. 5A, 5B). A detailed time course of incubation with these c-Met inhibitors demonstrated similar effects also in NIH:OVCAR-3 and SK-OV-3 cells which substantiated a continuously increasing and significant $\mathrm{G} 2 / \mathrm{M}$ phase accumulation already within $8 \mathrm{~h}$ to $12 \mathrm{~h}$ in the 4 different cell types (Suppl. Figs. S2A to S2D).

Examination of the $\mathrm{IC}_{50}$ for the two c-Met inhibitors demonstrated an about 10-fold increased sensitivity of SCCOHT-1 cells for foretinib (12.4 nM) compared to crizotinib (128 nM). Moreover, the ovarian adenocarcinoma cells NIH:OVCAR-3 and SK-OV-3 exhibited an about 2- and 3-fold enhanced sensitivity for foretinib whereas only little and insensitive differences were observed for BIN-67 cells (Fig. 5C). Together, these findings suggested a more specific growth inhibition associated with foretinib.

To test potential growth-inhibitory effects of foretinib in vivo, xenograft tumors were induced in $\mathrm{NOD}^{\text {scid }}$ mice by the two SCCOHT cell lines. Following a subcutaneous injection of $3 \times 10^{6}$ cells SCCOHT-1-induced mouse tumors $(n=3)$ could be detected already after $8 \mathrm{~d}$. A daily oral application of $200 \mu$ foretinib $(50 \mathrm{mg} / \mathrm{kg})$ for 10 subsequent days revealed a white/yellow-colored tumor tissue with an about 10 - to 20-fold reduced tumor mass compared to red-colored SCCOHT-1 control tumors $(n=3)$ after similar daily treatment with the solvent only (Fig. 6A). Following continuous tumor size measurements with corresponding calculation of the tumor volume, progressively increasing control tumors volumes were observed in contrast to an unaltered size of foretinibtreated tumors (Fig. 6B, upper panel). The relation of tumor weight / mouse weight after $10 \mathrm{~d}$ of treatment revealed $1.46 \pm 0.62 \%(n=3)$ in control tumors and an about 15 -fold reduced relation of $0.10 \pm 0.02 \%(n=3)$ in foretinib-treated SCCOHT-1 tumors (Fig. 6B, lower panel). Effects of foretinib treatment on the body weight of mice carrying SCCOHT-1 tumor xenografts revealed 
A.

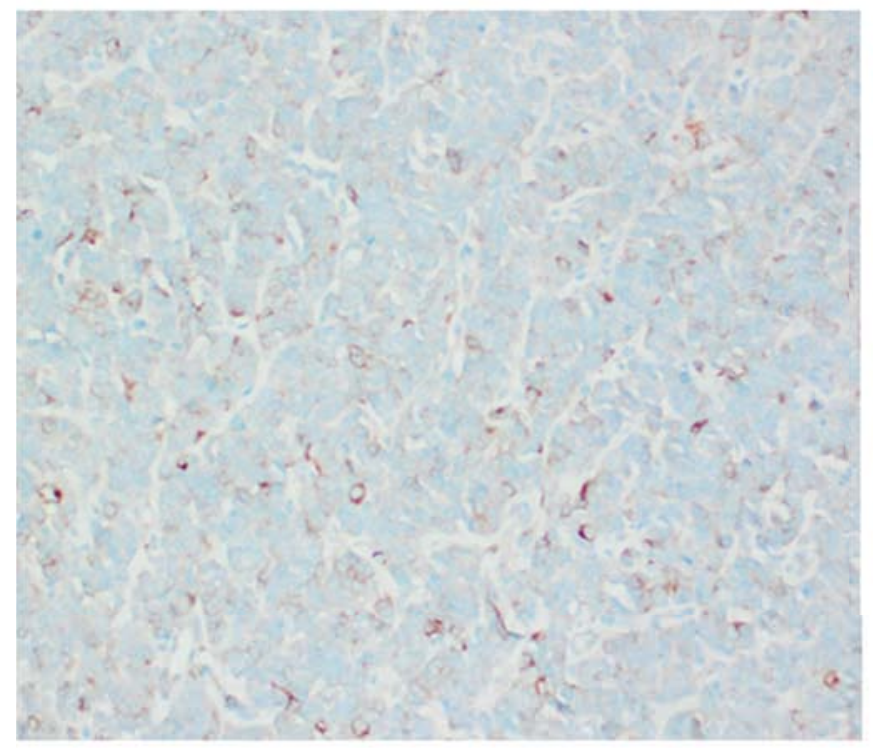

B.

\begin{tabular}{|c|c|c|c|}
\hline $\begin{array}{l}\text { Case } \\
\text { ID\# }\end{array}$ & Intensity & $\begin{array}{l}\text { Average } \\
\text { positive } \%\end{array}$ & Remarks \\
\hline MA1a & $2+$ & $60 \%$ & focal staining pattern \\
\hline MA2a & 0 & 0 & \\
\hline MA3a & 0 & 0 & \\
\hline MA4 & $2+$ & $80 \%$ & partially focal pattern \\
\hline MA5a & 0 & 0 & \\
\hline MA6a & $2+$ & $<1 \%$ & small positive foci \\
\hline MA7a & 0 & 0 & \\
\hline MA8a & $1+$ & $70 \%$ & \\
\hline MA9a & $2+$ & $<10 \%$ & \\
\hline MA10 & 0 & 0 & \\
\hline MA11 & $2+$ & $<1 \%$ & focal staining pattern \\
\hline MA12a & $2+$ & $<10 \%$ & focal staining pattern \\
\hline MA13 & $1+$ & $<1 \%$ & focal staining pattern \\
\hline MA14a & $1+$ & $<1 \%$ & single diffusely distributed cells \\
\hline MA15 & 0 & 0 & \\
\hline
\end{tabular}

\section{c-Met immunohistochemistry in SCCOHT patient tumors}

Figure 3: Immunhistochemical (IHC) detection of c-Met was performed in specimen of 16 different patients with confirmed SCCOHT. A. IHC analysis in the primary patient tumor (origin of SCCOHT-1 cells) confirmed c-Met expression at variable levels with predominantly membrane-bound staining. B. An additional pilot series $(n=15)$ of primary SCCOHT showed microscopically detectable c-Met expression together with the SCCOHT-1 originating tumor predominantly in 6/16 cases. The staining confirmed significant c-Met expression in a subset of SCCOHT and showed striking variability across cases and within individual tumors, suggesting intra- and intertumoral heterogeneity of c-Met expression.

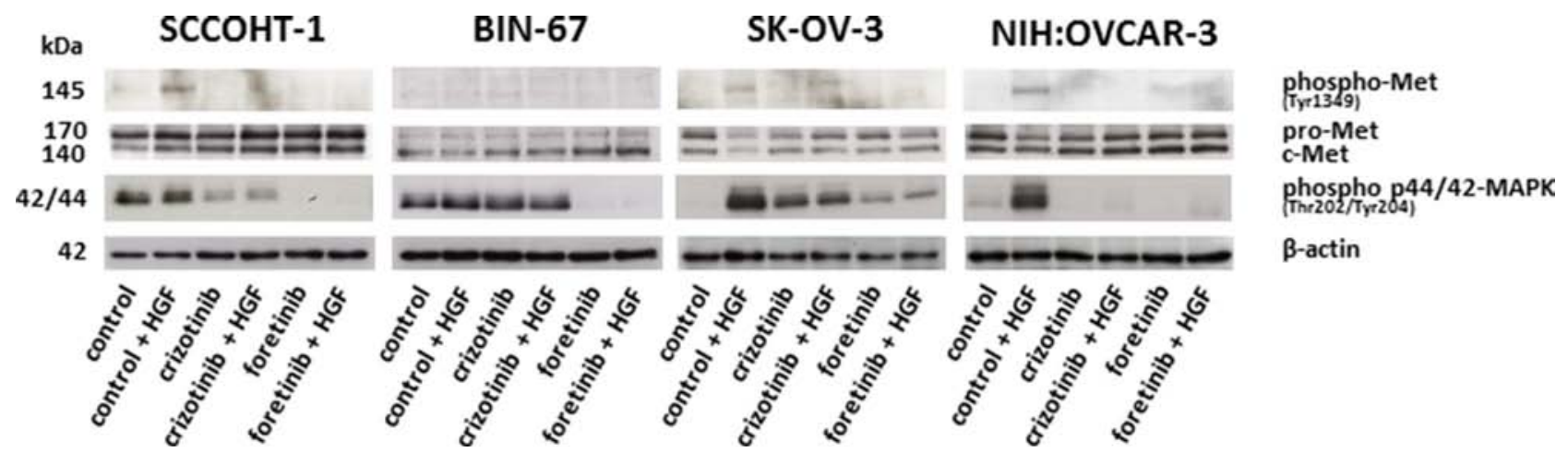

Figure 4: Western blot analysis was performed for c-Met phosphorylation at Tyr1349 and p44/p42 MAP kinase phosphorylation at Thre202/Tyr204 in SCCOHT-1, BIN-67, NIH:OVCAR-3 and SK-OV-3 ovarian cancer cells following $30 \mathrm{~min}$ of HGF stimulation in the presence or absence of the c-Met inhibitors crizotinib or foretinib, respectively.

less than $20 \%$ differences (up to $17 \% ; n=3 ; p<0.01$ ) compared to control treatment after 10d (Suppl. Fig. S4, left panel).

BIN-67-induced mouse tumors $(n=3)$ appeared after $71 \mathrm{~d}$ of subcutaneous tumor cell injection which took much longer to develop than SCCOHT-1 xenografts. This is also supported by the significantly reduced proliferative capacity of BIN-67 cells with an average cell doubling of approximately $75 \mathrm{~h}$ to $90 \mathrm{~h}$ compared to SCCOHT- 1 cells representing a cell doubling time between $24 \mathrm{~h}$ to $36 \mathrm{~h}$ (Suppl. Fig. S3).

A similar foretinib treatment of BIN-67-induced mouse tumors (daily oral application of $200 \mu$ foretinib $(50 \mathrm{mg} / \mathrm{kg})$ for $10 \mathrm{~d})$ was associated with an approximately 5-fold reduced tumor mass (Fig. 6C, left panel) and accordingly, the relation of tumor weight / mouse weight after $10 \mathrm{~d}$ of treatment declined by 4.6 -fold from $0.83 \pm$ $0.07 \%(n=3)$ in control tumors to $0.18 \pm 0.03 \%(n=3)$ in 


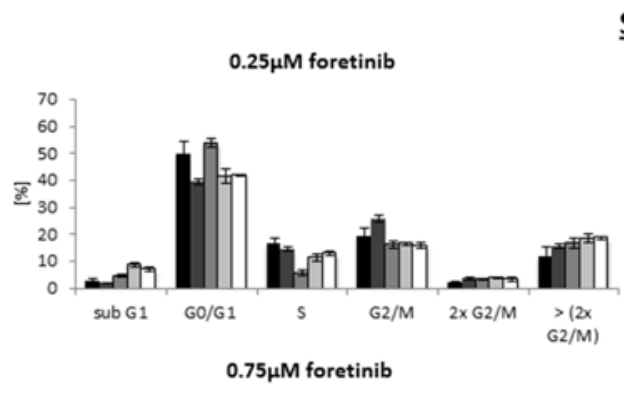

$\underline{\text { SCCOHT- } 1 \text { cells }}$
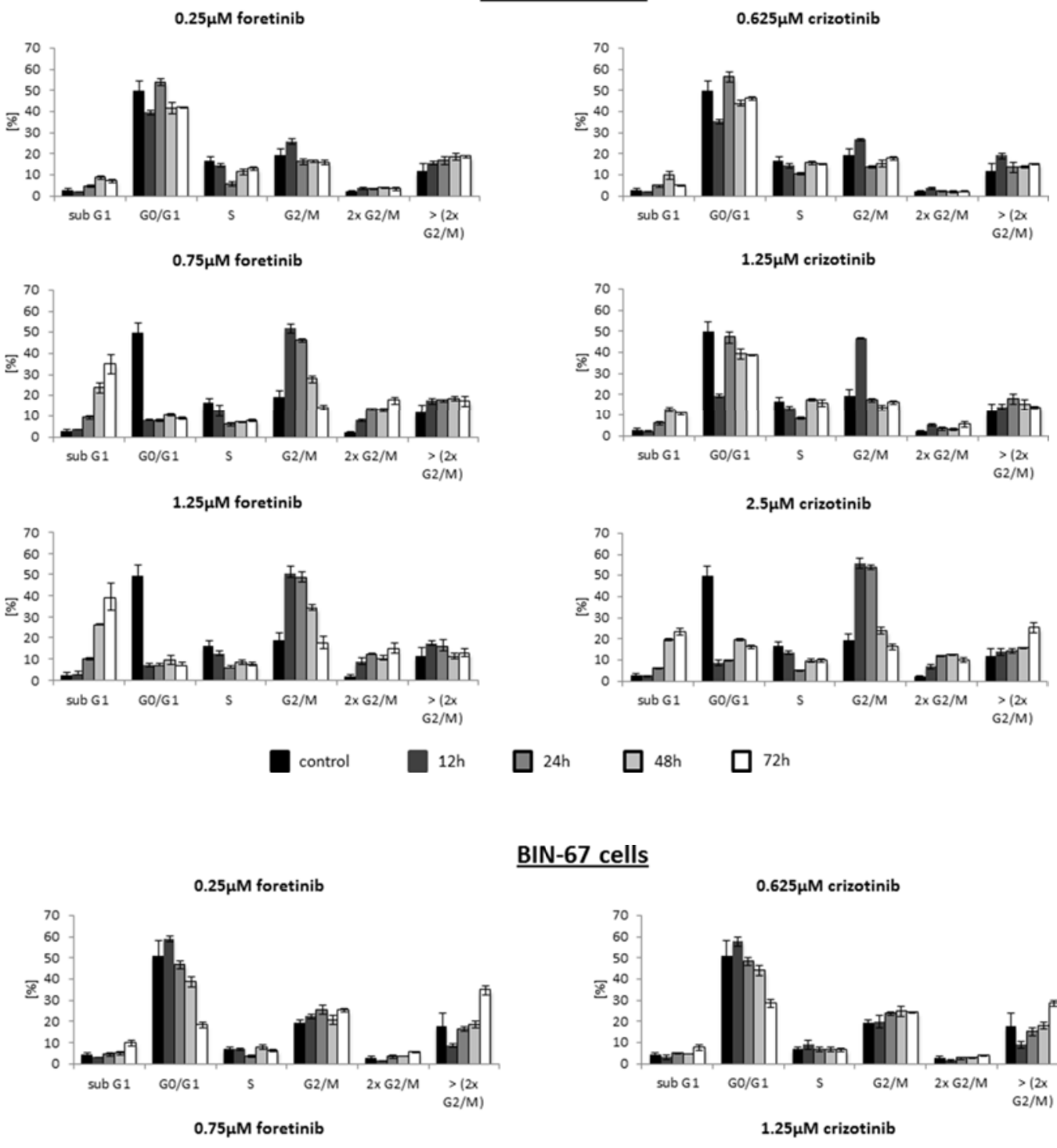

\section{BIN-67 cells}
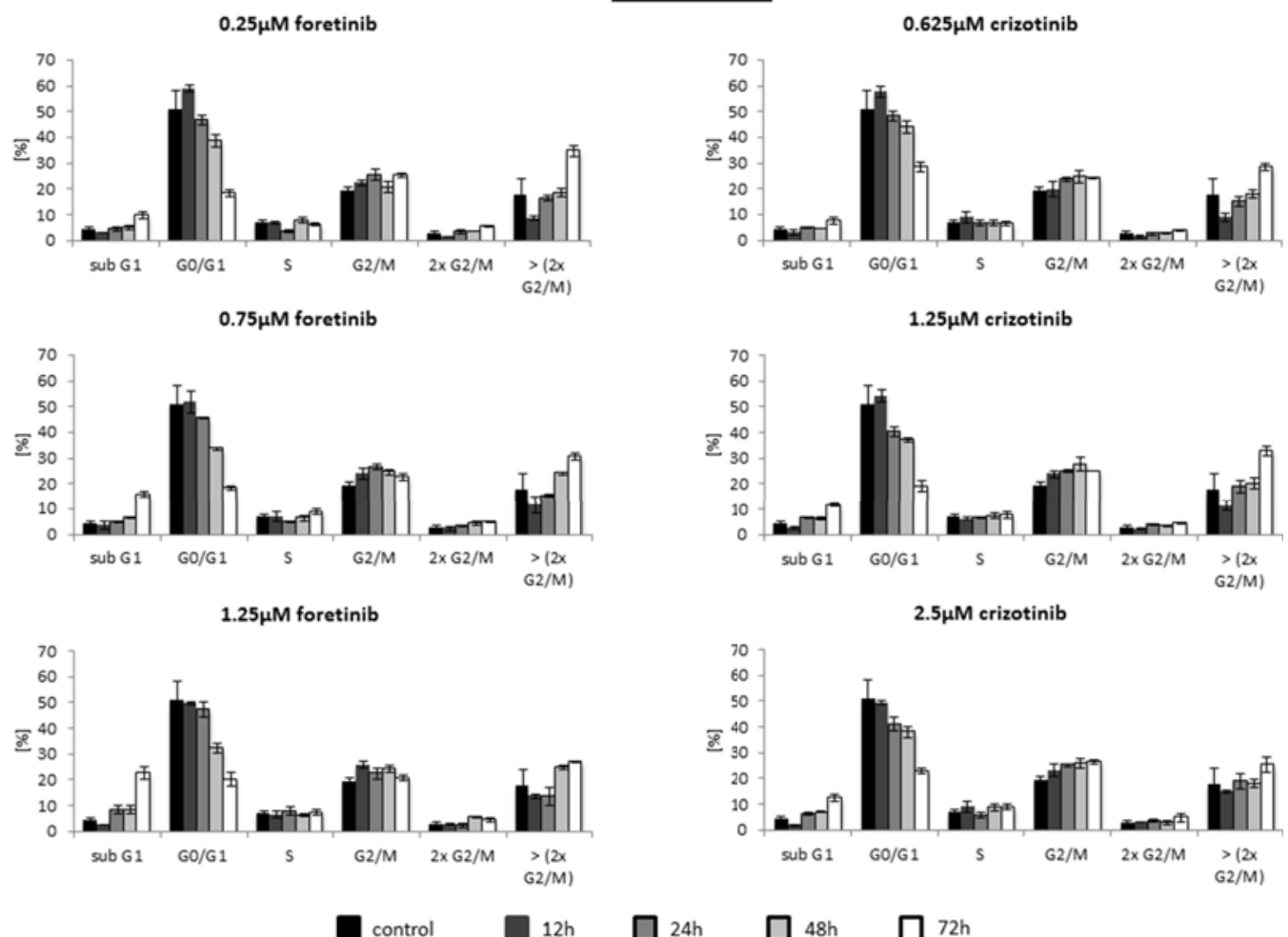

Figure 5: A. Cell cycle analysis was performed in SCCOHT-1, BIN-67 cells in the absence or presence of different concentrations of the c-Met inhibitors crizotinib and foretinib for $12 \mathrm{~h}$ up to $72 \mathrm{~h}$, respectively. Quantification of the different cell cycle phases represent the mean \pm s.d. $(n=3)$.

(Continued) 

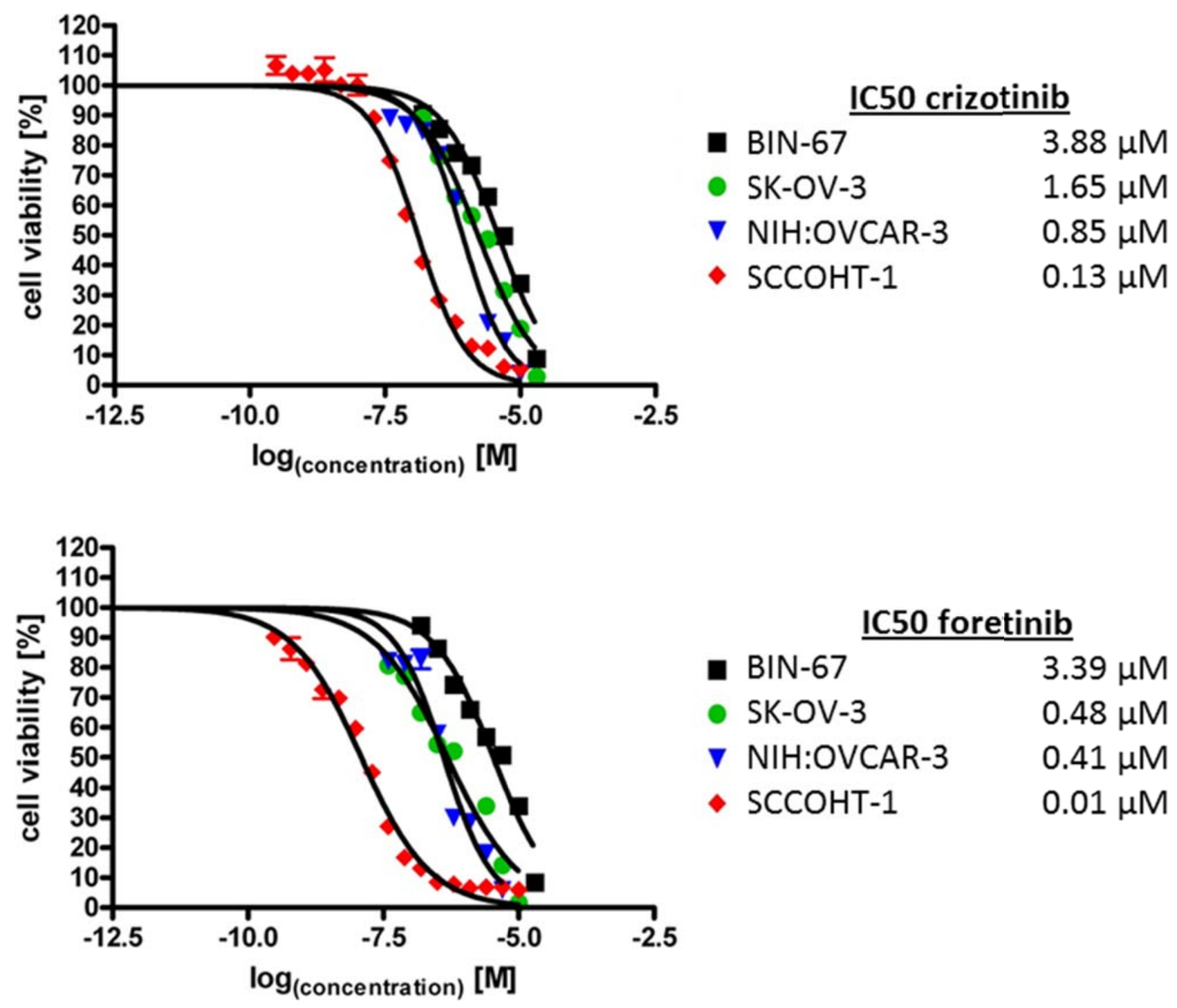

Figure 5: (Continued) B. SCCOHT-1 ${ }^{\mathrm{GFP}}$, BIN-67 $7^{\mathrm{GFP}}$, NIH:OVCAR-3 $3^{\mathrm{GFP}}$ and SK-OV-3 ${ }^{\mathrm{GFP}}$ ovarian cancer cells were incubated with different concentrations of crizotinib and foretinib for $72 \mathrm{~h}$, respectively, and the proliferative capacity was measured by the fluoroscan assay. Analysis of a drug-dose-response to define IC50 concentrations for crizotinib and foretinib was performed using GraphPad Prism-6. For calculation of the drug-dose-response curves, the data were normalized to the cells-only control in culture medium and to the maximal solvent (DMSO) concentration control of the two compounds, respectively.

foretinib-treated BIN-67 tumors (Fig. 6C, right panel). In parallel, the body weight of mice carrying BIN-67 tumor xenografts remained relatively constant and revealed no significant differences during foretinib treatment (Suppl. Fig. S4, right panel).

Further analysis by RT-PCR revealed a strong c-Met expression in SK-OV-3 and NIH:OVCAR-3 cells and low levels in BIN-67 cells. Expression of c-Met in SCCOHT-1 cells was also detectable in the original SCCOHT patient tumor and in SCCOHT-1-induced and BIN-67-induced tumor xenografts whereas a reduced expression appeared in both foretinib-treated tumors (Fig. 6D). Low levels of HGF transcripts in NIH:OVCAR-3, SK-OV-3, and BIN-67 cells were paralleled by nearly unaltered levels in SCCOHT-1 cells and the SCCOHT-1 in vivo tumors whereas the low HGF expression in BIN-67 in vivo tumors decreased to undetectable signals after foretinib treatment. Differences in the CD90 and EpCAM mRNA transcripts between the ovarian adenocarcinoma NIH:OVCAR-3 and SK-OV-3 compared to BIN-67 and SCCOHT-1 cells and associated in vivo tumors substantiated the special entity of SCCOHT tumors (Fig. 6D).

Analysis of c-Met protein expression in control tumor xenografts by Western blot revealed a reduction in both, the $170 \mathrm{kDa}$ preform and the $140 \mathrm{kDa}$ active HGF receptor following a 10 day foretinib treatment of the mice. Moreover, the phosphorylation signal of c-Met at Tyr1003 present in the control tumors was abolished after foretinib 


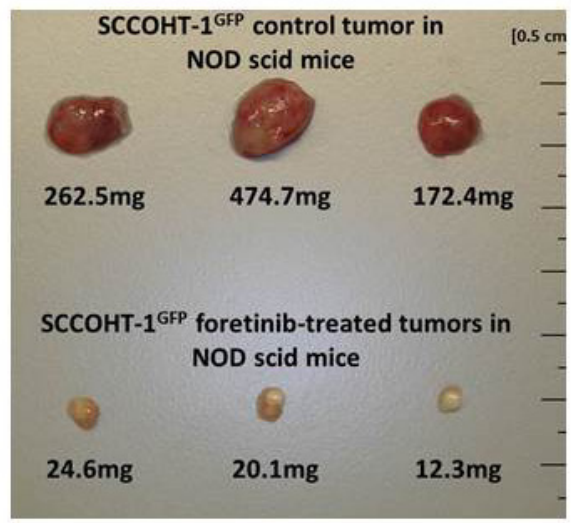

C

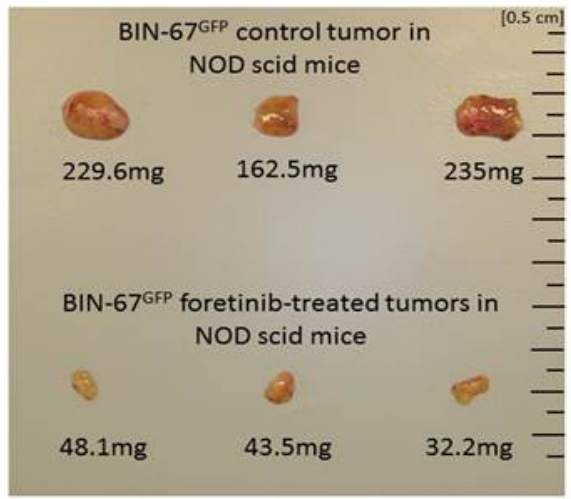

B
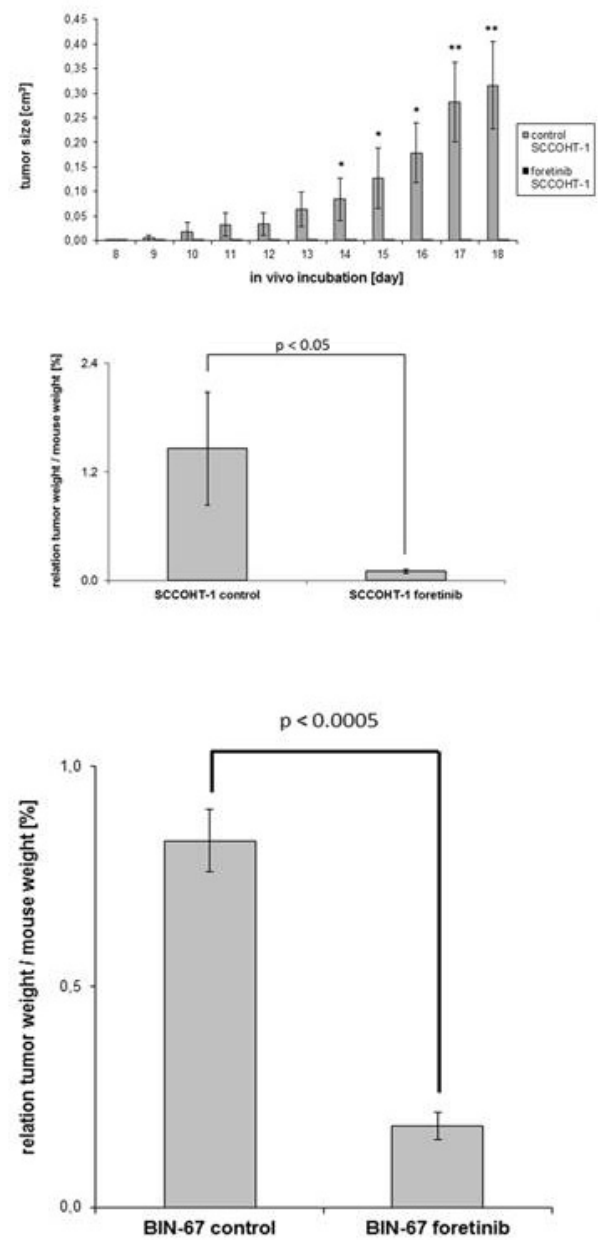

Figure 6: A. Size and weight of SCCOHT-1 ${ }^{\text {GFP }}$-induced tumors in NOD ${ }^{\text {seid }}$ mice was compared in the absence or presence of a 10 days therapeutic approach with foretinib. Following initial tumor detection, daily oral application was performed in 3 mice with $200 \mu \mathrm{l}$ foretinib at a concentration of $50 \mathrm{mg} / \mathrm{kg}$ dissolved in $30 \%(\mathrm{v} / \mathrm{v})$ propylene glycol, $5 \%(\mathrm{v} / \mathrm{v})$ Tween 80 , and $65 \%(\mathrm{v} / \mathrm{v})$ of a $5 \%(\mathrm{w} / \mathrm{v})$ dextrose solution in $\mathrm{H}_{2} \mathrm{O}$. The other 3 mice were used as controls by a daily oral application of $200 \mu \mathrm{l}$ of the solvent $(30 \%(\mathrm{v} / \mathrm{v})$ propylene glycol, $5 \%(\mathrm{v} / \mathrm{v})$ Tween 80 , and $65 \%(\mathrm{v} / \mathrm{v})$ of a $5 \%(\mathrm{w} / \mathrm{v})$ dextrose solution in $\mathrm{H} 2 \mathrm{O})$. After $10 \mathrm{~d}$ of therapy, all 6 mice were sacrificed by cervical dislocation and the GFP-positive tumors were dissected under UV light, washed in PBS, and weighted. B. The tumor size (upper panel) of SCCOHT- ${ }^{\text {GFP }}$-induced tumors in NOD ${ }^{\text {sid }}$ mice in the absence or presence of foretinib treatment was evaluated each day at 10 consecutive days of daily oral application as the mean \pm s.d. for control tumors $(n=3)$ and foretinib-treated tumors $(n=3)$. Statistical analysis was calculated by unpaired Student's t-test $\left({ }^{*} P<0.05 ; * * P<0.01\right)$. In the bottom panel, the relation of SCCOHT-1 tumor weight / mouse weight was calculated after $10 \mathrm{~d}$ of subsequent treatment as the mean \pm s.d. for control tumors $(n=3)$ and foretinib-treated tumors $(n=3)$. Statistical analysis was conducted by unpaired Student's t-test $\left({ }^{*} P<0.05\right)$. C. Size and weight of BIN-67 GFP-induced tumors in NOD ${ }^{\text {scid }}$ mice was compared in the absence or presence of a 10 days therapeutic approach with foretinib (left panel). The relation of BIN-67 tumor weight / mouse weight (right panel) was calculated after $10 \mathrm{~d}$ of subsequent treatment as the mean \pm s.d. for control tumors $(n=3)$ and foretinib-treated tumors $(n=3)$. Statistical analysis was conducted by unpaired Student's t-test $(* P<0.0005)$.

application (Fig. 6E). In addition, downstream signaling by phosphorylation of p44/42 MAPK remained undetectable in foretinib-treated tumors whereby GAPDH expression was used as a control (Fig. 6E). These data suggested that the significantly reduced tumor size was associated at least in part with interruption of c-Met signaling followed by growth arrest after foretinib exposure. Supportive data were obtained by immunohistochemistry of the in vivo
SCCOHT-1 (Fig. 6F) and BIN-67 (Fig. 6G) tumors. Staining with hematoxylin/eosin (HE) revealed various mitotic tumor cells in control tumor tissue in the vicinity of capillaries and microvessels. In contrast, less mitotic tumor cells and a significantly reduced vascularization were observed in the foretinib-treated tumors (Fig. 6F and $6 \mathrm{G}$, upper panel). Moreover, the proliferation marker Ki-67 stained the majority of cells in the control tumor 
(about 91\% in SCCOHT-1 and 31\% in BIN-67) whereas only about $54 \%$ of Ki-67-positive SCCOHT-1 cells and about $17 \%$ of Ki-67-positive BIN-67 cells were detectable after foretinib application (Fig. $6 \mathrm{~F}$ and $6 \mathrm{G}$, lower panel). Together, these findings substantiated an attenuation of SCCOHT-1- and BIN-67-mediated tumor growth paralleled by a reduced vascularization in the yellow foretinib-treated tumors, respectively.

The involvement of c-Met on cell growth was also tested by c-Met siRNA knock-down in SCCOHT-1. Transfection efficiency using an appropriate green fluorescing probe revealed about 92\% (Suppl. Fig. S5). Effects of the c-Met siRNA were confirmed by Western blot analysis. A pronounced c-Met expression was detectable in control SCCOHT-1 cells, in cells using the transfection reagent alone (transfection control), and in cells transfected with $25 \mathrm{nM}$ of a non-targeting control siRNA after $24 \mathrm{~h}$ (Fig. 7A). In contrast, down-modulation of c-Met protein was observed in c-Met siRNA-transfected SCCOHT-1 cells for up to $120 \mathrm{~h}$ (Fig. 7A). This downmodulation of c-Met in SCCOHT-1 caused a progressive growth reduction with a proliferative capacity of $35.1 \%$ $\pm 1.4 \%$ in c-Met siRNA-transfected cells as compared to about $100 \%$ in control cells and control transfectants after 72 h (Fig. 7B, upper panel). Moreover, c-Met siRNAmediated growth inhibition in SCCOHT-1 cells was also accompanied by an accumulation of apoptotic cells in subG1 and an increase in G0/G1 cell cycle phase with reduced $\mathrm{S}$ phase (Fig.7B, lower panel).

C-Met siRNA knock-down also abolished HGFmediated phosphorylation signaling of the receptor. Whereas SCCOHT-1 transfection control and cells transfected with a non-targeting siRNA demonstrated increased c-Met phosphorylation at Tyr1349 as well as more downstream an increased p44/p42 MAP kinase phosphorylation at Thr202/Tyr204 after $5 \mathrm{~min}$ to
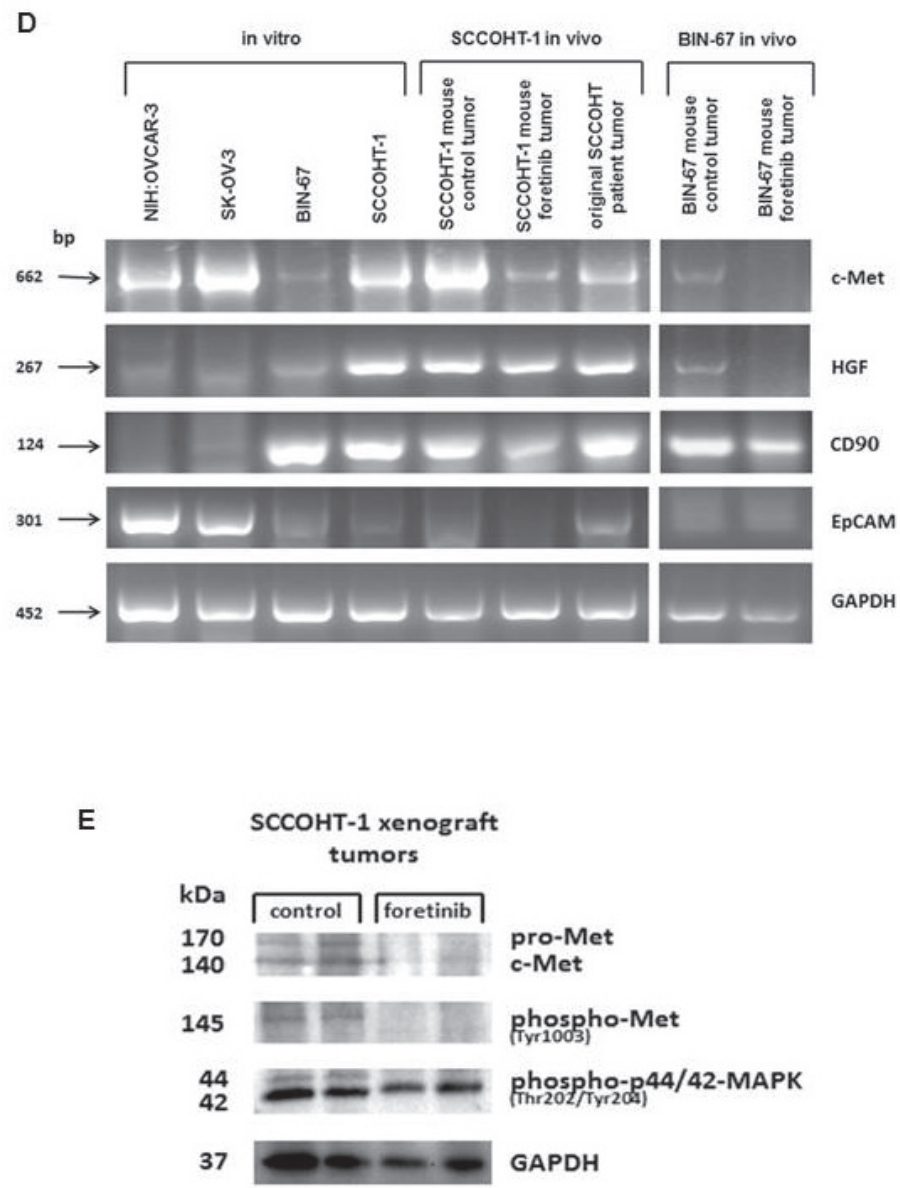

Figure 6: (Continued) D. The mRNA expression levels of various genes were analyzed by RT-PCR in the 4 ovarian cancer cell lines in vitro and compared to the in vivo NOD ${ }^{\text {scid }}$ SCCOHT-1 xenograft tumors together with the original patient tumor and to the in vivo BIN-67 ${ }^{\mathrm{GFP}}$ xenograft tumors following daily oral foretinib application for 10 consecutive days. E. Analysis of c-Met protein expression and associated phosphorylation signals in 2 control tumor xenografts (\#1.2 and \#1.3) was compared to 2 foretinib-treated tumor xenografts (\#2.3 and \#2.4) by Western blot analysis.

(Continued) 

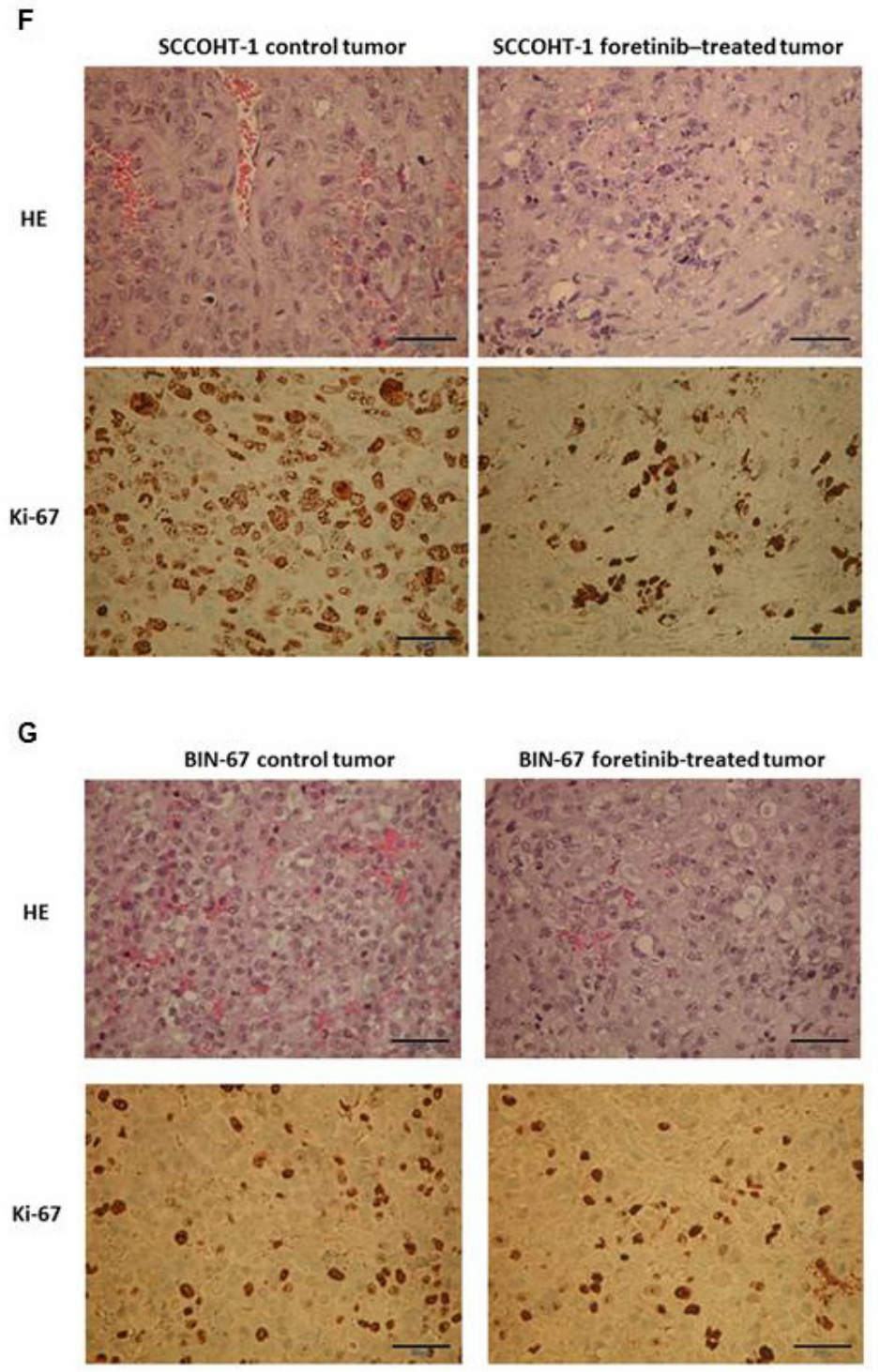

Figure 6: (Continued) F. Tissue sections $(4 \mu \mathrm{m})$ were prepared by hematoxylin/eosin staining (HE) of SCCOHT-1 ${ }^{\text {GFP }}$ induced control and foretinib-treated tumors in NOD ${ }^{\text {scid }}$ mice (upper panel; bars represent $50 \mu \mathrm{m}$ ). In addition, tissue sections $(4 \mu \mathrm{m})$ of control and foretinib-treated tumor xenografts were compared by immune histochemistry using the proliferation marker Ki-67 (lower panel; bars represent $50 \mu \mathrm{m}$ ). G. Tissue sections $(4 \mu \mathrm{m})$ were prepared by hematoxylin/eosin staining (HE) of BIN-67 $7^{\mathrm{GFP}}$-induced control and foretinib-treated tumors in NOD ${ }^{\text {scid }}$ mice (upper panel; bars represent $50 \mu \mathrm{m}$ ). In addition, tissue sections $(4 \mu \mathrm{m})$ of control and foretinib-treated tumor xenografts were compared by immune histochemistry using the proliferation marker Ki-67 (lower panel; bars represent $50 \mu \mathrm{m}$ ).

$20 \mathrm{~min}$ of stimulation with $20 \mathrm{ng} / \mathrm{ml} \mathrm{HGF}$, little if any phosphorylation signal was observed in c-Met siRNAtransfected SCCOHT-1 cells (Fig. 7C). Likewise, expression of the c-Met receptor itself remained undetectable in c-Met siRNA-transfected SCCOHT-1 cells in contrast to constitutive c-Met expression in SCCOHT-1 transfection control and cells transfected with a nontargeting siRNA (Fig. 7C).

At a more functional level, down-modulation of c-Met in SCCOHT-1 cells also reduced tumor growth in vivo. Whereas 1 mouse with a control tumor died during the experiment, 5 mice developed pronounced and partially red-colored tumors within 22d (Fig. 7D, upper panel) indicating an appropriate tumor vascularization. Similar data were obtained from tumors of 6 mice injected with non-coding siRNA-transfected SCCOHT$1^{\text {GFP }}$ cells (Fig. 7D, lower panel). In contrast, mouse tumor xenografts of c-Met siRNA-transfected SCCOHT-1 ${ }^{\text {GFP }}$ cells were observed only in 4/6 mice and appeared much smaller and less vascularized (Fig. 7D, middle panel). Calculation of the relation of tumor weight/mouse weight revealed $0.92 \pm 0.51(n=5)$ for the transfection control 
A.
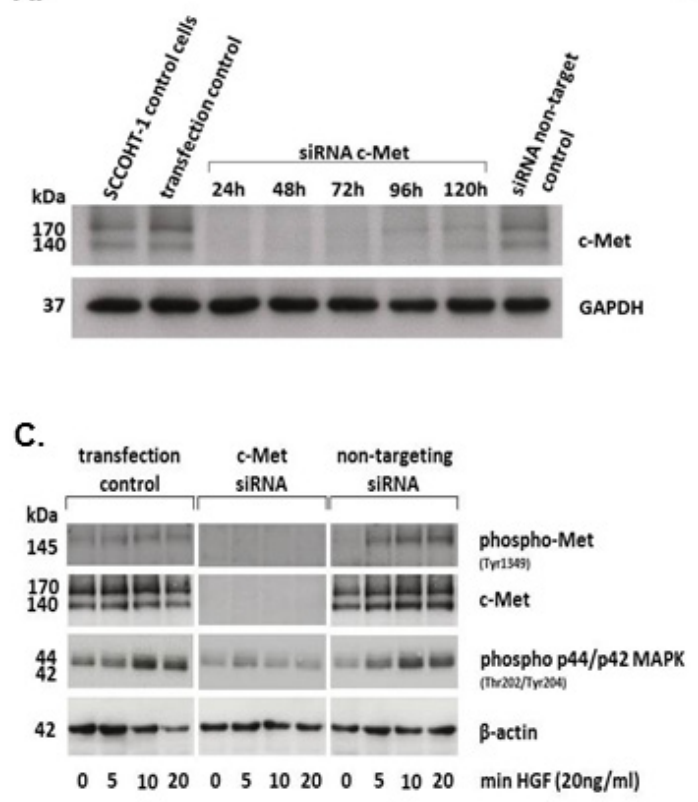

D.

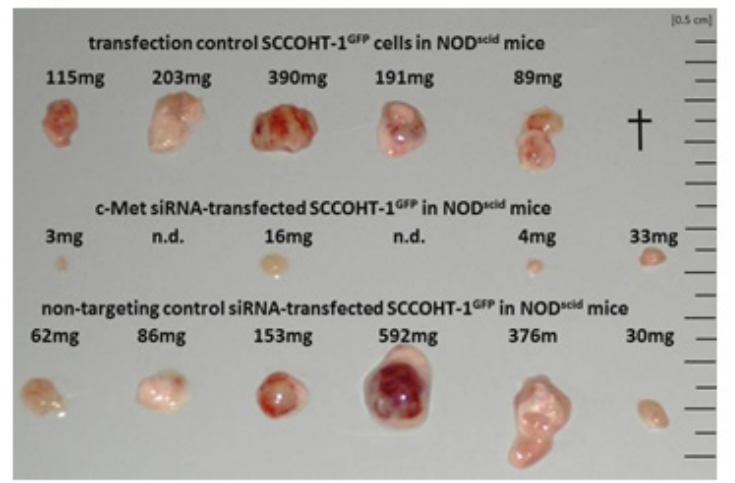

B.
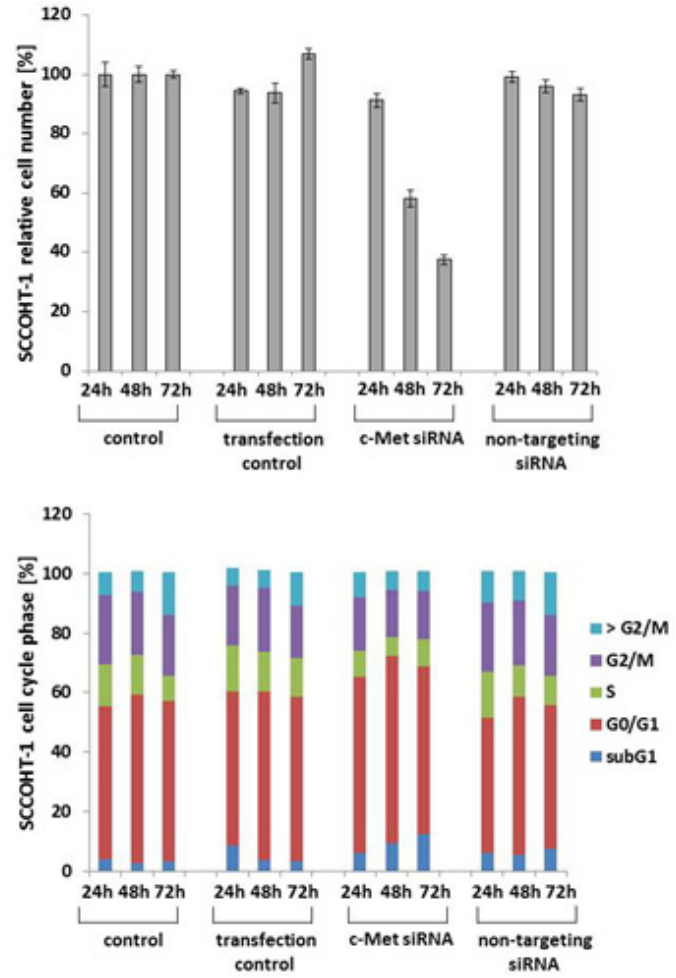

E.

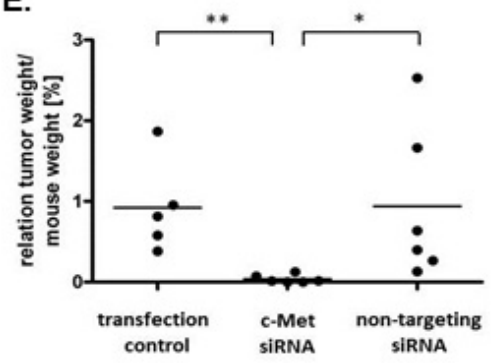

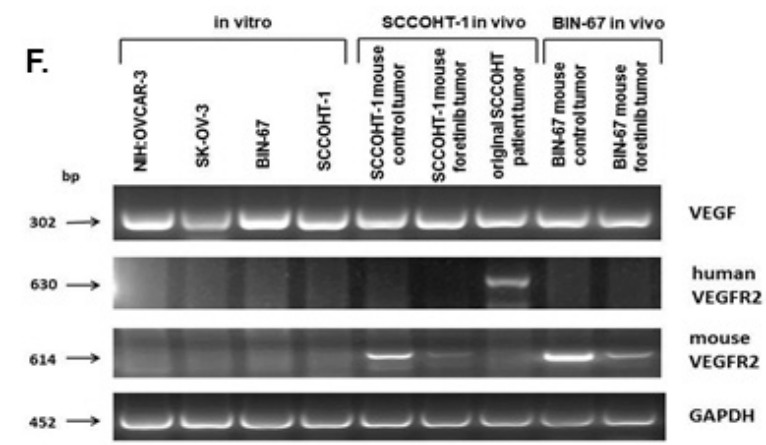

Figure 7: A. Western blot of c-Met in SCCOHT-1 steady state control cells, in cells using the transfection reagent alone (transfection control), and in cells with $25 \mathrm{nM}$ of a non-targeting control siRNA was performed $24 \mathrm{~h}$ after transfection. For c-Met siRNA-transfected SCCOHT-1 cells Western blots were performed between $24 \mathrm{~h}$ and $120 \mathrm{~h}$ post transfection. Analysis for GAPDH served as a loading control. B. Proliferative capacity (upper panel) and percentage of cell cycle phases (lower panel) of steady state SCCOHT-1 cells (control) was compared to cells after $24 \mathrm{~h}$ in the presence of the transfection reagent (transfection control), to cells transfected with c-Met siRNA (c-Met siRNA) and to cells transfected with a non-targeting siRNA (non-targeting siRNA). Cell numbers were counted for $24 \mathrm{~h}$ to $72 \mathrm{~h}$ and normalized ot the cell number of control cells $(=100 \%)$. Data represent the mean \pm s.d. of 3 independent experiments. C. Western blot of c-Met signaling was examined in SCCOHT-1 cells incubated with the transfection reagent for $24 \mathrm{~h}$ (transfection control), in cells transfected with $25 \mathrm{nM}$ c-Met siRNA (c-Met siRNA), and in cells transfected with $25 \mathrm{nM}$ of a non-targeting siRNA (non-targeting siRNA). In comparison to non-stimulated cells (0), the different populations were incubated with $20 \mathrm{ng} / \mathrm{ml} \mathrm{HGF}$ for $5 \mathrm{~min}, 10 \mathrm{~min}$, and $20 \mathrm{~min}$, respectively. Expression of $\beta$-actin was used as a loading control. 


\section{Figure 7: (Continued)}

D. In vivo tumor development was evaluated after $22 \mathrm{~d}$ of subcutaneous injection of $3 \times 10^{6}$ SCCOHT- ${ }^{\text {GFP }}$ cells $24 \mathrm{~h}$ after transfection into $6 \mathrm{NOD}^{\text {scid }}$ mice, respectively. Steady state control cells with transfection reagent (upper row) were compared to c-Met siRNA-mediated tumors (middle row) and tumors of a non-targeting control siRNA (lower row). In the control tumor section 1 mouse died in the course of the experiment ( $\dagger$, upper row). In the c-Met siRNA-transfected SCCOHT-1 cells 2 tumor developments were not detectable (n.d., middle row). Each tumor was verified by fluorescence microcopy demonstrating GFP expression. E. The relation of tumor weight / mouse weight of tumors from Fig. 7D was calculated Statistical analysis was conducted by unpaired Student's $t$-test $(* P<0.05 ; * * P<0.005)$. F. The mRNA expression levels of VEGF and human and mouse VEGFR2 was analyzed by RT-PCR in the 4 ovarian cancer cell lines in vitro and compared to the in vivo NOD ${ }^{\text {sid }}$ SCCOHT-1 and BIN-6 $67^{\text {GFP }}$ xenograft tumors together with the original patient tumor of SCCOHT- 1 cells. GAPDH expression levels served as a control.

and $0.94 \pm 0.8(n=6)$ for the non-targeting siRNAinduced tumors. In contrast, c-Met siRNA-mediated tumors displayed an approximately 20 -fold reduced ratio of $0.04 \pm 0.04(n=6)$ (Fig. 7E).

Together, these data demonstrated an attenuation of tumor growth in SCCOHT-1 cells by targeting c-Met via antisense or via c-Met signaling interference compounds including foretinib. However, BIN-67 cells express only background levels of c-Met although foretinib treatment exhibited a significant tumor reduction which suggested additional effects of this compound. Indeed, foretinib treatment was also associated with interference of vascular endothelial growth factor (VEGF) signaling. Whereas VEGF was expressed by the ovarian tumor cell lines and by the SCCOHT tumors, transcripts of the related receptor VEGFR2 appeared species-specific and were observed exclusively in the corresponding human and mouse tumors, respectively (Fig. 7F). In particular, VEGFR2 expression exclusively in the original SCCOHT patient tumor but not in the corresponding SCCOHT-1 cells which were derived from this human tumor suggested paracrine VEGF effects by expression of this receptor in tumor-associated tissue rather than in the tumor cells. Moreover, foretinib treatment significantly reduced the VEGFR2 expression in the mouse tumors furthermore supporting additional effects of this drug also on the tumor microenvironment e.g. by reduced vascularization (Fig.7F).

\section{DISCUSSION}

SCCOHT represents a rare and aggressive tumor type with unclear etiology and insufficient therapeutic strategies. Whereas mutations in the SMARCA4 gene and certain similarities to malignant rhabdoid tumors are known for this cancerous disease [14-16, 20] further characterization of the corresponding cellular models SCCOHT-1 and BIN-67 demonstrated significant differences in surface marker and filament expression compared to ovarian adenocarcinoma cells and therefore confirmed SCCOHT as a separate tumor entity with distinct growth properties. However, the growth factor receptor c-Met revealed common presences in the ovarian adenocarcinoma cells and to a lesser extend in SCCOHT-1 and BIN-67 cells.

The membrane receptor c-Met (Mesenchymal epithelial transition factor), also known as hepatocyte growth factor/scatter factor receptor is essential for embryonic development and wound healing [27]. In tumors, however, including ovarian cancer, c-MET overexpression and paralleled hyperactivation correlates with poor prognosis by triggering tumor growth, metastasis and angiogenesis [28-30]. Constitutive c-Met expression and enhanced angiogenic properties in SCCOHT-1 cells are also supported by their capacity of to produce and release VEGF and VCAM-1 into the tumor microenvironment which are essential for tumor neovascularization. Likewise, IL-8 (CXCL8) is associated with angiogenesis besides an involvement in inflammatory processes [31]. Moreover, the distinct chemokine/ growth factor production by SCCOHT-1 cells including a constitutive HGF production suggested an autocrine loop for c-Met-relayed proliferation signals which could serve as a more specific therapeutic target in these cells. Additional exogenous HGF stimulation resulted in c-Met phosphorylation and enhanced downstream signaling by elevated p44/42-MAP kinase activation in SCCOHT-1 and the ovarian adenocarcinoma cells. Indeed, several phosphorylation sites are identified in the cytoplasmic c-Met domain to confer Erk/MAP kinase activation for induced proliferation and cell cycle progression in a variety of different tumor types including ovarian cancer [32-34]. Targeted approaches to antagonize aberrant c-Met signaling include therapeutic intervention in 1) ligand/receptor interaction, 2) inhibition of the tyrosine kinase catalytic activity, and 3) blockade of activated receptor/effector interaction. Thus, crizotinib and foretinib represent multi-targeted tyrosine kinase inhibitors to block c-Met signaling whereby foretinib was even more efficient to completely abolish both, constitutive and HGF-induced c-Met and subsequent MAP kinase phosphorylation in the ovarian adenocarcinoma as well as in the small cell hypercalcemic ovarian cancer cells. Simultaneously, these c-Met inhibitors effectively inhibited proliferation of the tumor cells by a pronounced G2/M cell cycle arrest and confirmed previous findings in foretinib- 
treated SK-OV-3 cells [35]. Since foretinib appears as a more potent inhibitor than crizotinib also in patients with ROS1-rearranged non-small-cell lung carcinoma [36], further in vivo studies revealed anti-tumorigenic effects of foretinib in lung metastasis [37] and in patients with sonic hedgehog-driven medulloblastoma [38]. In the present study, we could demonstrate a substantial therapeutic effect of foretinib by attenuating growth of SCCOHT-1- and BIN-67-induced tumors although SCCOHT-1 xenograft tumors developed much more rapidly. Both populations provide a cellular model for the rare SCCOHT whereby detectable c-Met expression was observed preferably in SCCOHT-1 cells and in the majority of SCCOHT tumor samples. Consequently, c-Met and associated targets by foretinib treatment represent a potential therapeutic approach for this tumor entity. Moreover, foretinib displayed additional effects by downmodulation of the VEGFR2 within the SCCOHT tumor microenvironment and thereby reduced cancer growth also in BIN-67-induced tumors with little or barely detectable c-Met expression.

Together, interference with c-Met signaling in vivo significantly diminished the SCCOHT-1 and BIN-67 tumor sizes, respectively. This effect was paralleled by a marked reduction of growth-associated structures in the tumor microenvironment such as tumor vascularization. Supportive evidence for anti-tumor activity of foretinib by inhibition of c-Met and vascular endothelial growth factor receptor 2 was obtained in models of hepatocellular carcinoma [39], renal cell carcinoma [40], and gastric cancer [41] which also underscores the importance to simultaneously target the tumor microenvironment by blocking neo-vascularization. In this context, interaction of SCCOHT-1 tumor cells by a close vicinity to mesenchymal stroma/stem cells in the tumor microenvironment can transfer proteins, RNAs and further biological material thereby altering cellular functionality and contributing to increased tumor heterogeneity [42-46].

In conclusion, the data suggested that in all presently available models of the rare SCCOHT tumor entity the attenuation of in vivo SCCOHT-1 or BIN-67 tumor growth and vascularization blockage by foretinib provides a specific target to further support a combination with cytotoxic agents in a promising therapeutic approach.

\section{MATERIAL AND METHODS}

\section{Cell culture}

\section{Culture of human SCCOHT cells}

Cellular models of SCCOHT are represented by the two cell lines BIN-67 and SCCOHT-1. BIN67 were kindly provided by Dr. Barbara Vanderhyden (University of Ottawa, Canada) and cultured with DMEM/
F12 : DMEM medium (1:1) (Sigma Aldrich, St. Louis, MO) supplemented with $20 \%(\mathrm{v} / \mathrm{v})$ fetal calf serum, $2 \mathrm{mM}$ L-glutamine, $100 \mathrm{U} / \mathrm{ml}$ penicillin and $100 \mu \mathrm{g} / \mathrm{ml}$ streptomycin [21].

SCCOHT-1 cells were generated in our lab as a spontaneously growing primary culture derived from a tumor biopsy of a 31-year-old patient with recurrent SCCOHT [18]. The study has been approved by the Ethics Committee of Hannover Medical School, Project \#3916 on June 15th, 2005 and informed written consent was obtained from the patient for the use of this material. The SCCOHT-1 cells were cultured in RPMI 1640 supplemented with $10 \%(\mathrm{v} / \mathrm{v})$ fetal calf serum, $100 \mathrm{U} / \mathrm{ml} \mathrm{L}$-glutamine, $100 \mathrm{U} / \mathrm{ml}$ penicillin and $100 \mu \mathrm{g} / \mathrm{ml}$ streptomycin. Serum-free cultures of SCCOHT-1 were maintained in HybridoMed DIF 1000 medium (Biochrom, Berlin, Germany). The cell culture was performed at $37^{\circ} \mathrm{C}$ in a humidified atmosphere of $5 \%(\mathrm{v} / \mathrm{v}) \mathrm{CO}_{2}$ and the culture medium was changed at intervals of 3 to 4 days. For subculture, the cells were centrifuged (320 g/6 min) and resuspended in the appropriate growth medium.

\section{Human ovarian adenocarcinoma cell lines}

Human NIH:OVCAR-3 ovarian cancer cells (ATCC $^{\circledR}$ \#HTB-161 ${ }^{\mathrm{TM}}$ ) were commercially obtained in passage 76 (P76) from the Institute for Applied Cell Culture (IAZ), Munich, Germany. The SK-OV-3 ovarian cancer cells $\left(\mathrm{ATCC}^{\circledR}\right.$ \#HTB-77TM) were commercially obtained in P25 from the ATCC, Manassas, VA, USA. These two cell lines were originally established from the malignant ascites of a patient with progressive adenocarcinoma of the ovary, respectively. Both cell types were cultivated at about 1,750 cells $/ \mathrm{cm}^{2}$ in RPMI 1640 supplemented with $10 \%(\mathrm{v} / \mathrm{v})$ fetal calf serum, $100 \mathrm{U} / \mathrm{ml}$ L-glutamine, $100 \mathrm{U} / \mathrm{ml}$ penicillin and $100 \mu \mathrm{g} / \mathrm{ml}$ streptomycin. Subculture was performed by trypsin/EDTA (Biochrom GmbH, Berlin, Germany) treatment for $5 \mathrm{~min}$ at $37^{\circ} \mathrm{C}$.

\section{Cell line authentication}

All cells were tested for mycoplasma by the luminometric MycoAlert Plus mycoplasma detection kit (Lonza Inc., Rockland, ME, USA) according to the manufacturer's recommendations. Moreover, authentication of SCCOHT-1, BIN-67, NIH:OVCAR-3, and SK-OV-3 cell lines was performed by short tandem repeat (STR) fragment analysis using the GenomeLab human STR primer set (Beckman Coulter Inc., Fullerton, CA, USA). The fragment analysis for the NIH:OVCAR-3 and SK-OV-3 cell lines demonstrated a similar STR pattern according to the STR database provided by the Deutsche Sammlung von Mikroorganismen und Zellkulturen (DSMZ, Braunschweig, Germany). 
Whereas no STR patterns are available for SCCOHT-1 and BIN-67 cells to date, repeated STR fragment analyses were performed for these two cell populations. Data from different SCCOHT-1 culture periods $(n=3)$ confirmed similar patterns and these STR pattern were presented in Suppl. Fig. S6.

\section{Cytokine production and release}

Following culture of $2 \times 10^{5} / \mathrm{ml}$ SCCOHT- 1 cells in serum-free HybridoMed DIF 1000 medium, supernatants were collected after $48 \mathrm{~h}$ and $72 \mathrm{~h}$, respectively. The conditioned medium was filtered in a $0,2 \mu \mathrm{m}$ filter (Sartorius Stedim Biotech GmbH, Göttingen, Germany) to remove cells and debris, and aliquots were shockfrozen in liquid nitrogen and stored at $-80^{\circ} \mathrm{C}$ until measurement. Aliquots of the supernatants were applied to a Quantibody ${ }^{\circledR}$ array (RayBiotech Inc., Norcross, GA, USA / tebu-bio GmbH, Offenbach, Germany), which represents a quantitative array platform by using a multiplexed sandwich ELISA-based technology. This method allows to simultaneously and quantitatively determine the concentration of multiple cytokines. Membranes of the Quantibody Human Chemokine Array (RayBiotech Inc./ tebu-bio $\mathrm{GmbH}$ ) were incubated with the cell supernatants in comparison to control medium in quadruplicates and developed by chemiluminescence according to the manufacturer's instructions. Chemokine concentrations were measured (based on internal controls) in $\mathrm{pg} / \mathrm{ml}+$ s.d. $(n=4)$ using appropriate manufacturer's software.

\section{Analysis of surface markers by flow cytometry}

Continuously proliferating SCCOHT-1, BIN-67, NIH:OVCAR-3 and SK-OV-3 cells in logarithmic growth phase were harvested and analyzed for cell surface marker expression by flow cytometry. After blocking non-specific binding to $\mathrm{Fc}$-receptors by incubation of $10^{6}$ cells with $2 \% \mathrm{FCS}$ for $30 \mathrm{~min}$ at $4^{\circ} \mathrm{C}$ and washing with PBS-BSA, the cells were incubated with the following appropriately-labeled monoclonal anti-human antibodies, respectively: c-Met-FITC (clone eBioclone97, IgG1, eBioscience, Inc., San Diego, CA, USA); CD29-PE (clone MAR4, IgG1, BD Biosciences, Heidelberg, Germany); CD44-FITC (clone G44-26, IgG2b, BD Biosciences); CD90-PE (clone 5E10, IgG1, BioLegend Inc., San Diego, CA, USA); CD105-PE (clone 43A3, IgG1, BioLegend Inc.); CD326-PE (clone G9C4, IgG2b, BioLegend Inc.); vimentin-PE (clone VI-RE-1, IgG1, antibodies-online Inc., Atlanta, GA, USA); pan-cytokeratin-PE (clone C-11, IgG1, Acris Antibodies GmbH, Herford, Germany); Following antibody staining, all samples were washed twice with PBS-BSA. Moreover, SCCOHT-1, BIN-67,
NIH:OVACAR-3 and SK-OV-3 cells were incubated with a primary monoclonal anti-human mesothelin antibody (clone K1, IgG1, abcam plc, Cambridge, UK), respectively, followed by two washes with PBS-BSA and subsequent addition of a secondary PE-labeled polyclonal rabbit anti-mouse antibody (DakoCytomation Inc., Glostrup, Denmark).

A parallel incubation of the cells with appropriatelylabeled antibodies of the corresponding Ig subclass were used as controls. Flow cytometry analysis was performed in a Galaxy FACSan (Partec) using FloMax analysis software (Partec).

\section{Immunohistochemical c-Met analysis in SCCOHT patient tumors}

Immunohistochemistry was performed on an automated staining instrument (Benchmark Ultra; Ventana, Tuscon, U.S.A) using the $\mathrm{CC} 1$ mild antigen retrieval procedure and a monoclonal anti-c-Met antibody (clone D1C2, rabbit, Cell Signaling Technology, Danvers, MA, USA), diluted at 1:100 in primary antibody diluent following the manufacturer's recommendations. Semiquantitative slide evaluation by two observers $(\mathrm{RH} / \mathrm{FF})$ included scoring of staining intensity $(0,1+, 2+, 3+)$ and estimation of percentage of positive cells in $10 \%$ increments.

\section{Immunoblot analysis}

Cell lysates of SCCOHT-1, BIN-67, NIH:OVCAR-3 or SK-OV-3 cells were prepared in reswelling buffer containing $8 \mathrm{M}$ urea (Carl Roth GmbH Co KG, Karlsruhe, Germany), 1\% CHAPS (3-[(3-Cholamidopropyl)-dimethylammonio]-1propanesulfonate) (Carl Roth $\mathrm{GmbH}$ Co KG), 0.5\% (v/v) Pharmalyte 3-10 (GE Healthcare Europe GmbH, Freiburg, Germany), 0.002\% (w/v) bromophenol blue (SERVA Electrophoresis GmbH, Heidelberg, Germany) and freshly prepared $0.4 \%(\mathrm{w} / \mathrm{v})$ DTT (Dithiothreitol) (Carl Roth GmbH Co KG). Protein concentration of the cell lysates was adjusted using the colorimetric BCAassay (Thermo Scientific, Schwerte, Germany). Aliquots of $40 \mu \mathrm{g}$ protein were subjected to SDS-polyacrylamide gel electrophoresis and transferred to a Amersham ${ }^{\mathrm{TM}}$ Protran ${ }^{\text {TM}_{-}}$-Supported $0.45 \mu \mathrm{m}$ nitrocellulose membrane (GE Healthcare). The membranes were blocked with PBS containing 5\% low fat milk and $0.05 \%$ Tween-20 (PBS/Tween). After washing four times with PBS/ Tween, the membranes were incubated with the primary antibodies: monoclonal anti-c-Met (clone D1C2, rabbit, (dilution 1:1,000); Cell Signaling Technology, Danvers, MA, USA); monoclonal anti-phospho-Met (Tyr1349) (clone 130H2, rabbit, (dilution 1:1,000); Cell Signaling Technology); monoclonal anti-phospho-Met (Tyr1003) 
(clone 13D11, rabbit, (dilution 1:1000), Cell Signaling Technology); polyclonal anti-phospho p44/42 MAP kinase (Thr202/Tyr204) (rabbit, (dilution 1:1,000), Cell Signaling Technology); monoclonal anti-GAPDH (clone 6C5, mouse, (dilution 1:200), Santa Cruz Biotechnology Inc., Dallas, Texas, USA); monoclonal anti- $\beta$-actin (clone AC-15, mouse, (dilution 1:1,000), Sigma, St. Louis, Missouri, USA). Thereafter, the membranes were washed four times with PBS/Tween and incubated with the appropriate horseradish peroxidase-conjugated anti-mouse IgG (dilution 1:5,000) or anti-rabbit IgG (dilution 1:2,000) secondary antibody, respectively, (all from GE Healthcare, Freiburg, Germany) for $1 \mathrm{~h} /$ room temperature. The membranes were washed with PBS/Tween and visualized by autoradiography using SuperSignal West Pico Chemiluminescent Substrate (Thermo Scientific, Schwerte, Germany).

\section{Cell cycle analysis}

Cell cycle analysis compared to untreated controls was performed in $5 \times 10^{5}$ SCCOHT-1, BIN-67, NIH:OVCAR-3 or SK-OV-3 cells after culture either in the presence of $0.025 \%(\mathrm{v} / \mathrm{v})$ DMSO (Sigma) as solvent, $2.5 \mu \mathrm{M}$ crizotinib, or $1.25 \mu \mathrm{M}$ foretinib (= GSK1363089; = PF-02341066) (both from Selleck Chemicals LLC, Houston,TX,USA) for up to $72 \mathrm{~h}$, respectively. The cells were fixed in $70 \%(\mathrm{v} / \mathrm{v})$ ice-cold ethanol at $4^{\circ} \mathrm{C}$ for $24 \mathrm{~h}$. Thereafter, the fixed cells were stained with CyStain DNA 2 step kit (Partec $\mathrm{GmbH}$, Münster, Germany) and filtered through a $50 \mu \mathrm{m}$ filter. Flow cytometry analysis was performed in a Galaxy FACSan (Partec) using FloMax analysis software (Partec).

\section{Proliferation rate}

The proliferative capacity and the sensitivity of SCCOHT-1, BIN-67, NIH:OVCAR-3 and SK-OV-3 cells was determined for different concentrations of crizotinib and foretinib. In a fluorescence-based proliferation assay the ovarian cancer cell types were transduced with a 3rd generation lentiviral SIN vector containing the eGFP gene as previously described for these cells $[18,19]$. The different eGFP-transduced ovarian cancer cell populations (SCCOHT-1 ${ }^{\mathrm{GFP}}$, BIN-67 ${ }^{\mathrm{GFP}}$, NIH:OVCAR-3 ${ }^{\mathrm{GFP}}$ and SK-OV-3 ${ }^{\mathrm{GFP}}$ ) were incubated with culture medium in flat bottom 96-well plates (Nunc/ThermoFischer) at a density of $3 \times 10^{3}$ cells/ well and following incubation for $24 \mathrm{~h}, 48 \mathrm{~h}$, and $72 \mathrm{~h}$, the medium was removed and the cells were lysed with $5 \%(\mathrm{w} / \mathrm{v})$ SDS. Afterwards, the fluorescence intensities of GFP in the cell homogenate which corresponded to the appropriate cell number of ovarian cancer cells was measured at excitation $485 \mathrm{~nm} /$ emission 520 nm using the Fluoroscan Ascent Fl (Thermo Fisher Scientific).

\section{In vivo experiments}

Animal research using NOD ${ }^{\text {sid }}$ mice was carried out by following internationally recognized guidelines on animal welfare and has been approved by the institutional licensing committee ref. \#33.14-4250204-12/0814 on June 26th, 2012.

About $3 \times 10^{6}$ SCCOHT- $1^{\text {GFP }}$ or BIN-67 ${ }^{\text {GFP }}$ cells were injected subcutaneously into 5 weeks old female $\operatorname{NOD}^{\text {sid }}$ mice ( $n=6$ for each cell line). Within 8 days, the 6 SCCOHT-1-treated mice and after 71d the other 6 BIN-67-treated mice had developed small subcutaneous tumors. Systemic therapy was performed in 3 mice of both cell line-induced tumors by a daily oral application of $200 \mu \mathrm{l}$ foretinib (GSK1363089) $(50 \mathrm{mg} / \mathrm{kg})$ (Selleck Chemicals LLC) dissolved in $30 \%(\mathrm{v} / \mathrm{v})$ propylene glycol, $5 \%(\mathrm{v} / \mathrm{v})$ Tween 80 , and $65 \%(\mathrm{v} / \mathrm{v})$ of a $5 \%(\mathrm{w} / \mathrm{v})$ dextrose solution in $\mathrm{H}_{2} \mathrm{O}$. The other 3 mice of both cell line-induced tumors were used as controls by a daily oral application of $200 \mu \mathrm{l}$ of the solvent $(30 \%$ (v/v) propylene glycol, $5 \%(\mathrm{v} / \mathrm{v})$ Tween 80 , and $65 \%(\mathrm{v} / \mathrm{v})$ of a $5 \%(\mathrm{w} / \mathrm{v})$ dextrose solution in $\mathrm{H}_{2} \mathrm{O}$ ). Although foretinib in clinical studies is administered to patients between $3.6 \mathrm{mg} / \mathrm{kg}$ to $4.5 \mathrm{mg} / \mathrm{kg}$ [47], in vivo mouse experiments including recent studies are performed at foretinib concentrations of $60 \mathrm{mg} / \mathrm{kg}$ to $100 \mathrm{mg} / \mathrm{kg}$ [38].

Oral application was performed using plastic feeding tubes $(18 \mathrm{ga} \times 30 \mathrm{~mm}$ ) (Instech Laboratories, Plymouth, PA, USA). Following 10d of therapy, the 6 mice of each cell line-induced tumors were sacrificed by cervical dislocation. Tumor volumes (V) of SCCOHT-1 tumors were calculated with the longitudinal diameter (length) and the transverse diameter (width) in the modified ellipsoidal formula $\mathrm{V}=\pi / 6$ * width * (length $)^{2}$ [48].

The GFP-positive tumors were dissected under UV light, washed in PBS, weighted and either cryo-preserved in liquid nitrogen for subsequent PCR and Western blot analysis or fixed in $4 \%$ glutardialdehyde solution for histopathological evaluations.

\section{Transcript analysis by RT-PCR}

Total RNA was isolated from cells and tumor tissues using RNeasy Mini Kit (Qiagen, Hilden, Germany) according to the manufacturer's instructions. One $\mu \mathrm{g}$ RNA was reverse transcribed into cDNA using $500 \mu \mathrm{M}$ of dNTP (R0193), $5 \mu \mathrm{M}$ Oligo(dT) 18 primer (S0132), $5 \mu \mathrm{M}$ Random Hexan primer (S0142), 1 U RiboLockTM RNase Inhibitor (E00381) and 5 U RevertAidTM M-MuLV Reverse Transcriptase (EP0441) in the supplied reaction buffer (all reagents from Thermo Scientific, Schwerte, Germany). The cDNA reactions were performed for $10 \mathrm{~min} / 25^{\circ} \mathrm{C}, 1 \mathrm{~h} / 37^{\circ} \mathrm{C}$ 
and stopped at $72{ }^{\circ} \mathrm{C}$ for $10 \mathrm{~min}$. As a template $2.5 \mu \mathrm{l}$ of cDNA was used with primers specific for:

- Hepatocyte growth factor (scatter factor) (HGF) (sense: 5'-AGG AGA AGG CTA CAG GGG CAC-3'; antisense: 5'-TTT TTG CCA TTC CCA CGA TAA3'; amplification product $267 \mathrm{bp}$ ) [49];

- c-Met (sense: 5'-CAG GCA GTG CAG CAT GTA GTG-3'; antisense: 5'-TAA GGT GGG GCT CCT CTT GTC A-3'; amplification product 662 bp) [50];

- CD90 (sense: 5'-GGA CTG AGA TCC CAG AAC CA-3'; antisense: 5'-ACG AAG GCT CTG GTC CAC TA-3'; amplification product $124 \mathrm{bp)} \mathrm{[51]);}$

- EpCAM (sense: 5'-GAA GGC TGA GAT AAA GGA GAT GGG-3'; antisense: 5'-TTA ACG ATG GAG TCC AAG TTC TGG-3' amplification product $301 \mathrm{bp)}$ [52];

- VEGF-A (sense: 5'-CCT CAG TGG GCA CAC ACT CC-3'; antisense: 5'-CGA AAC CAT GAA CTT TCT GC-3' amplification product 302bp) [53]

- human VEGF-R2 (sense: 5'-TTA CAG ATC TCC ATT TAT TGC-3'; antisense: 5'-TTC ATC TCA CTC CCA GAC T-3' amplification product 630bp) [54]

- mouse VEGF-R2 (sense: 5'-ATA ACC TGG CTG ACC CGA TTC -3'; antisense: 5'-TCG GTG ATG TAC ACG ATG CC-3' amplification product 614 bp)

- GAPDH as a control PCR (sense: 5'-ACC ACA GTC CAT GCC ATC AC-3'; antisense: 5'-TCC ACC ACC CTG TTG CTG TA-3'; amplification product 452 bp [55])

was performed (all primers customized by Eurofins, MWG GmbH, Ebersberg, Germany). PCR reactions included $0.2 \mu \mathrm{M}$ of each primer, $200 \mu \mathrm{M}$ of dNTP (R0193, Thermo Scientific) and 0.05 U Taq DNA Polymerase (EPO402, Thermo Scientific) in the supplied reaction buffer. PCR cycling conditions were performed $30 \mathrm{sec}$ at $94^{\circ} \mathrm{C}, 1 \mathrm{~min}$ at $60^{\circ} \mathrm{C}$ and $72^{\circ} \mathrm{C}$ for $1 \mathrm{~min}$ respectively, including an initial $30 \mathrm{sec}$ denaturation step at $94^{\circ} \mathrm{C}$ and a final $10 \mathrm{~min}$ extension step at $72^{\circ} \mathrm{C}(35$ cycles $)$. Aliquots of $25 \mu \mathrm{l}$ of each RT-PCR product were separated on a $2 \%$ agarose gel including the standard GeneRuler 100 bp DNA Ladder (Thermo Scientific) and visualized by GelRedTM (Biotium Inc., Hayward, CA, US) staining.

\section{siRNA knock-down of c-Met}

For c-Met knock-down a transfection protocol was applied according to the manufacturer's instructions (Dharmacon, GE Healthcare, Uppsala, Sweden) using c-Met small interfering RNA (siRNA). Briefly, SCCOHT-1 cells were transfected with $25 \mathrm{nM}$ c-Met siRNA (siGENOME human MET SMARTpool, cat. \#D-003156-02) or with $25 \mathrm{nM}$ of a non-targeting control siRNA (non-targeting \#3 control, cat. \#D-001210-03, Dharmacon, GE Healthcare, Uppsala, Sweden) using a 1:1,000 dilution of the DharmaFECT 4 transfection reagent (Dharmacon) in transfection medium (RPMI-1640 medium supplemented with $2 \%(\mathrm{v} / \mathrm{v})$ fetal calf serum, $100 \mathrm{U} / \mathrm{ml} \mathrm{L}$-glutamine) for $24 \mathrm{~h}$. For evaluation of the transfection efficiency, SCCOHT-1 cells were transfected with $25 \mathrm{nM}$ of the green fluorescing siGLO ${ }^{\text {green }}$ (cat. \#D-001630-01, Dharmacon). Thereafter, the cells were washed and cultured in normal growth medium.

\section{ACKNOWLEDGMENT}

The authors are grateful to Dr. Marc-Jens Kleppa for helpful advices and providing some transfection reagent.

\section{GRANT SUPPORT}

This work was supported by a grant from the Niedersächsiche Krebsgesellschaft to Ralf Hass.

\section{CONFLICTS OF INTEREST}

The authors declare no conflict of interest. All authors have critically read and approved the present manuscript.

\section{REFERENCES}

1. Kurman RJ, Visvanathan K, Roden R, Wu TC, Shih Ie M. Early detection and treatment of ovarian cancer: shifting from early stage to minimal volume of disease based on a new model of carcinogenesis. American journal of obstetrics and gynecology. 2008; 198:351-356.

2. Kurman RJ, Shih Ie M. The origin and pathogenesis of epithelial ovarian cancer: a proposed unifying theory. The American journal of surgical pathology. 2010; 34:433-443.

3. Kim A, Ueda Y, Naka T, Enomoto T. Therapeutic strategies in epithelial ovarian cancer. J Exp Clin Cancer Res. 2012; 31:14.

4. Dubeau L. The cell of origin of ovarian epithelial tumours. The Lancet. 2008; 9:1191-1197.

5. Hafner N, Nicolaus K, Weiss S, Frey M, Diebolder H, Rengsberger M, Durst M, Runnebaum IB. p53-autoantibody may be more sensitive than CA-125 in monitoring microscopic and macroscopic residual disease after primary therapy for epithelial ovarian cancer. Journal of cancer research and clinical oncology. 2013; 139:1207-1210.

6. Dickersin GR, Kline IW, Scully RE. Small cell carcinoma of the ovary with hypercalcemia: a report of eleven cases. Cancer. 1982; 49:188-197.

7. Young RH, Oliva E, Scully RE. Small cell carcinoma of the hypercalcemic type in the ovary. Gynecologic oncology. $1995 ; 57: 7-8$. 
8. Scully RE. Tumors of the Ovary and Maldeveloped Gonads. Atlas of Tumor Pathology: Washington, DC, Armed Forces Institute of Pathologym, 1979; 233-242.

9. Ulbright TM, Roth LM, Stehman FB, Talerman A, Senekjian EK. Poorly differentiated (small cell) carcinoma of the ovary in young women: evidence supporting a germ cell origin. Human pathology. 1987; 18:175-184.

10. Aguirre P, Thor AD, Scully RE. Ovarian small cell carcinoma. Histogenetic considerations based on immunohistochemical and other findings. American journal of clinical pathology. 1989; 92:140-149.

11. Walt H, Hornung R, Fink D, Dobler-Girdziunaite D, Stallmach T, Spycher MA, Maly F, Haller U, Burki N. Hypercalcemic-type of small cell carcinoma of the ovary: characterization of a new tumor line. Anticancer research. 2001; 21:3253-3259.

12. McCluggage WG, Oliva E, Connolly LE, McBride HA, Young RH. An immunohistochemical analysis of ovarian small cell carcinoma of hypercalcemic type. Int J Gynecol Pathol. 2004; 23:330-336.

13. Ramos P, Karnezis AN, Hendricks WP, Wang Y, Tembe W, Zismann VL, Legendre C, Liang WS, Russell ML, Craig DW, Farley JH, Monk BJ, Anthony SP, Sekulic A, Cunliffe HE, Huntsman DG, et al. Loss of the tumor suppressor SMARCA4 in small cell carcinoma of the ovary, hypercalcemic type (SCCOHT). Rare Diseases. 2014; 2:e967148.

14. Jelinic P, Mueller JJ, Olvera N, Dao F, Scott SN, Shah R, Gao J, Schultz N, Gonen M, Soslow RA, Berger MF, Levine DA. Recurrent SMARCA4 mutations in small cell carcinoma of the ovary. Nature genetics. 2014; 46:424-426.

15. Witkowski L, Carrot-Zhang J, Albrecht S, Fahiminiya S, Hamel N, Tomiak E, Grynspan D, Saloustros E, Nadaf J, Rivera B, Gilpin C, Castellsague E, Silva-Smith R, Plourde F, Wu M, Saskin A, et al. Germline and somatic SMARCA4 mutations characterize small cell carcinoma of the ovary, hypercalcemic type. Nature genetics. 2014; 46:438-443.

16. Ramos P, Karnezis AN, Craig DW, Sekulic A, Russell ML, Hendricks WP, Corneveaux JJ, Barrett MT, Shumansky K, Yang Y, Shah SP, Prentice LM, Marra MA, Kiefer J, Zismann VL, McEachron TA, et al. Small cell carcinoma of the ovary, hypercalcemic type, displays frequent inactivating germline and somatic mutations in SMARCA4. Nature genetics. 2014; 46:427-429.

17. Upchurch KS, Parker LM, Scully RE, Krane SM. Differential cyclic AMP responses to calcitonin among human ovarian carcinoma cell lines: a calcitonin-responsive line derived from a rare tumor type. J Bone Miner Res. 1986; 1:299-304.

18. Otte A, Gohring G, Steinemann D, Schlegelberger B, Groos S, Langer F, Kreipe HH, Schambach A, Neumann T, Hillemanns P, Park-Simon TW, Hass R. A tumor-derived population (SCCOHT-1) as cellular model for a small cell ovarian carcinoma of the hypercalcemic type. International journal of oncology. 2012; 41:765-775.

19. Otte A, Rauprich F, Hillemanns P, Park-Simon TW, von der Ohe J, Hass R. In vitro and in vivo therapeutic approach for a small cell carcinoma of the ovary hypercalcaemic type using a SCCOHT-1 cellular model. Orphanet journal of rare diseases. 2014; 9:126.

20. Foulkes WD, Clarke BA, Hasselblatt M, Majewski J, Albrecht S, McCluggage WG. No small surprise - small cell carcinoma of the ovary, hypercalcaemic type, is a malignant rhabdoid tumour. The Journal of pathology. 2014; 233:209-214.

21. Gamwell L, Gambaro K, Merziotis M, Crane C, Arcand SL, Bourada V, Davis C, Squire JA, Huntsman DG, Tonin PN, Vanderhyden BC. Small cell ovarian carcinoma: genomic stability and responsiveness to therapeutics. Orphanet journal of rare diseases. 2013; 8 .

22. Otte A, Rauprich F, von der Ohe J, Hillemanns P, Hass R. Interference of $\mathrm{Ca}(2)(+)$ with the proliferation of SCCOHT-1 and ovarian adenocarcinoma cells. International journal of oncology. 2014; 45:1151-1158.

23. Majore I, Moretti P, Hass R, Kasper C. Identification of subpopulations in mesenchymal stem cell-like cultures from human umbilical cord. Cell Commun Signal. 2009; 7:6.

24. Lavrentieva A, Majore I, Kasper C, Hass R. Effects of hypoxic culture conditions on umbilical cord-derived human mesenchymal stem cells. Cell Commun Signal. 2010; 8:18.

25. Pirozzi G, Tirino V, Camerlingo R, Franco R, La Rocca A, Liguori E, Martucci N, Paino F, Normanno N, Rocco G. Epithelial to mesenchymal transition by TGFbeta-1 induction increases stemness characteristics in primary non small cell lung cancer cell line. PloS one. 2011; 6:e21548.

26. Chang K, Pastan I. Molecular cloning of mesothelin, a differentiation antigen present on mesothelium, mesotheliomas, and ovarian cancers. Proceedings of the National Academy of Sciences of the United States of America. 1996; 93:136-140.

27. Birchmeier C, Birchmeier W, Gherardi E, Vande Woude GF. Met, metastasis, motility and more. Nature reviews. 2003; 4:915-925.

28. Parr C, Jiang WG. Expression of hepatocyte growth factor/ scatter factor, its activator, inhibitors and the c-Met receptor in human cancer cells. International journal of oncology. 2001; 19:857-863.

29. Yamashita Y, Akatsuka S, Shinjo K, Yatabe Y, Kobayashi H, Seko H, Kajiyama H, Kikkawa F, Takahashi T, Toyokuni S. Met is the most frequently amplified gene in endometriosis-associated ovarian clear cell adenocarcinoma and correlates with worsened prognosis. PloS one. $2013 ; 8:$ e57724. 
30. Tang C, Jardim DL, Hong D. MET in ovarian cancer: metastasis and resistance? Cell cycle. Georgetown, Tex: 2014; 13:1220-1221.

31. Brat DJ, Bellail AC, Van Meir EG. The role of interleukin-8 and its receptors in gliomagenesis and tumoral angiogenesis. Neuro-oncology. 2005; 7:122-133.

32. Organ SL, Tsao MS. An overview of the c-MET signaling pathway. Therapeutic advances in medical oncology. 2011; 3:S7-S19.

33. Mhawech-Fauceglia P, Afkhami M, Pejovic T. MET/ HGF Signaling Pathway in Ovarian Carcinoma: Clinical Implications and Future Direction. Pathology research international. 2012; 2012:960327.

34. Blumenschein GR, Jr., Mills GB, Gonzalez-Angulo AM. Targeting the hepatocyte growth factor-cMET axis in cancer therapy. J Clin Oncol. 2012; 30:3287-3296.

35. Zillhardt M, Park SM, Romero IL, Sawada K, Montag A, Krausz T, Yamada SD, Peter ME, Lengyel E. Foretinib (GSK1363089), an orally available multikinase inhibitor of c-Met and VEGFR-2, blocks proliferation, induces anoikis, and impairs ovarian cancer metastasis. Clin Cancer Res. 2011; 17:4042-4051.

36. Davare MA, Saborowski A, Eide CA, Tognon C, Smith RL, Elferich J, Agarwal A, Tyner JW, Shinde UP, Lowe SW, Druker BJ. Foretinib is a potent inhibitor of oncogenic ROS1 fusion proteins. Proceedings of the National Academy of Sciences of the United States of America. 2013; 110:19519-19524.

37. Qian F, Engst S, Yamaguchi K, Yu P, Won KA, Mock L, Lou T, Tan J, Li C, Tam D, Lougheed J, Yakes FM, Bentzien F, Xu W, Zaks T, Wooster R, et al. Inhibition of tumor cell growth, invasion, and metastasis by EXEL-2880 (XL880, GSK1363089), a novel inhibitor of HGF and VEGF receptor tyrosine kinases. Cancer research. 2009; 69:8009-8016.

38. Faria CC, Golbourn BJ, Dubuc AM, Remke M, Diaz RJ, Agnihotri S, Luck A, Sabha N, Olsen S, Wu X, Garzia L, Ramaswamy V, Mack SC, Wang X, Leadley M, Reynaud D, et al. Foretinib is effective therapy for metastatic sonic hedgehog medulloblastoma. Cancer research. 2015; 75:134-146.

39. Huynh H, Ong R, Soo KC. Foretinib demonstrates antitumor activity and improves overall survival in preclinical models of hepatocellular carcinoma. Angiogenesis. 2012; 15:59-70.

40. Choueiri TK, Vaishampayan U, Rosenberg JE, Logan TF, Harzstark AL, Bukowski RM, Rini BI, Srinivas S, Stein MN, Adams LM, Ottesen LH, Laubscher KH, Sherman L, McDermott DF, Haas NB, Flaherty KT, et al. Phase II and biomarker study of the dual MET/VEGFR2 inhibitor foretinib in patients with papillary renal cell carcinoma. J Clin Oncol. 2013; 31:181-186.
41. Shah MA, Wainberg ZA, Catenacci DV, Hochster HS, Ford J, Kunz P, Lee FC, Kallender H, Cecchi F, Rabe DC, Keer H, Martin AM, Liu Y, Gagnon R, Bonate P, Liu L, et al. Phase II study evaluating 2 dosing schedules of oral foretinib (GSK1363089), cMET/VEGFR2 inhibitor, in patients with metastatic gastric cancer. PloS one. 2013; 8:e54014.

42. Ungefroren H, Sebens S, Seidl D, Lehnert H, Hass R. Interaction of tumor cells with the microenvironment. Cell Commun Signal. 2011; 9:18.

43. Hass R, Otte A. Mesenchymal stem cells as all-round supporters in a normal and neoplastic microenvironment. Cell Commun Signal. 2012; 10:26.

44. Mandel K, Yang Y, Schambach A, Glage S, Otte A, HassR. Mesenchymal stem cells directly interact with breast cancer cells and promote tumor cell growth in vitro and in vivo. Stem cells and development. 2013; 22:3114-3127.

45. Yang Y, Otte A, Hass R. Human mesenchymal stroma/stem cells exchange membrane proteins and alter functionality during interaction with different tumor cell lines. Stem cells and development. 2015; 24:1205-1222.

46. Yang Y, Bucan V, Baehre H, von der Ohe J, Otte A, Hass R. Acquisition of new tumor cell properties by MSCderived exosomes. International journal of oncology. 2015; 47:244-252.

47. Eder JP, Shapiro GI, Appleman LJ, Zhu AX, Miles D, Keer H, Cancilla B, Chu F, Hitchcock-Bryan S, Sherman L, McCallum S, Heath EI, Boerner SA, LoRusso PM. A phase I study of foretinib, a multi-targeted inhibitor of c-Met and vascular endothelial growth factor receptor 2 . Clin Cancer Res. 2010; 16:3507-3516.

48. Tomayko MM, Reynolds CP. Determination of subcutaneous tumor size in athymic (nude) mice. Cancer chemotherapy and pharmacology. 1989; 24:148-154.

49. Hollborn M, Krausse C, Iandiev I, Yafai Y, Tenckhoff S, Bigl M, Schnurrbusch UE, Limb GA, Reichenbach A, Kohen L, Wolf S, Wiedemann P, Bringmann A. Glial cell expression of hepatocyte growth factor in vitreoretinal proliferative disease. Laboratory investigation; a journal of technical methods and pathology. 2004; 84:963-972.

50. Pons E, Uphoff CC, Drexler HG. Expression of hepatocyte growth factor and its receptor c-met in human leukemia-lymphoma cell lines. Leukemia research. 1998; 22:797-804.

51. Montanucci P, Basta G, Pescara T, Pennoni I, Di Giovanni F, Calafiore R. New simple and rapid method for purification of mesenchymal stem cells from the human umbilical cord Wharton jelly. Tissue engineering. 2011; 17:2651-2661.

52. Andratschke M, Hagedorn H, Luebbers CW, Schmitt B, Lang S, Zeidler R, Wollenberg B. Limited suitability of EpCAM for molecular staging of tumor borders in head and neck cancer. Anticancer research. 2006; 26:153-158. 
53. Simpson DA, Feeney S, Boyle C, Stitt AW. Retinal VEGF mRNA measured by SYBR green I fluorescence: A versatile approach to quantitative PCR. Molecular vision. 2000; 6:178-183.

54. Schuch G, Machluf M, Bartsch G, Jr., Nomi M, Richard H, Atala A, Soker S. In vivo administration of vascular endothelial growth factor (VEGF) and its antagonist, soluble neuropilin-1, predicts a role of VEGF in the progression of acute myeloid leukemia in vivo. Blood. 2002; 100:4622-4628.

55. Marconi C, Peppicelli S, Bianchini F, Calorini L. TNFalpha receptor1 drives hypoxia-promoted invasiveness of human melanoma cells. Experimental oncology. 2013; 35:187-191. 